Policy Research Working Paper 9016

\title{
Broken Promises
}

\section{Evaluating an Incomplete Cash Transfer Program}

\author{
Angelika Müller \\ Utz Pape \\ Laura Ralston
}

\section{WORLD BANK GROUP}

Poverty and Equity Global Practice

$\&$

Social Protection and Jobs Global Practice

September 2019 
Policy Research Working Paper 9016

\begin{abstract}
Interventions in highly insecure and fragile contexts are always confronted with the latent risk of not being able to implement the program as intended. Despite its high policy relevance, little is known about the impacts of program disruption or cancellation on beneficiaries. This study uses the unplanned cancellation of the South Sudan Youth Business Start-Up Grant Program to assess the socioeconomic, behavioral, and psychological consequences of a program that fails to be implemented as intended. Originally planned as a randomized trial, the Youth Startup Business Grant Program consisted of an unconditional cash grant combined with a business and life skills training targeting the youth in South Sudan. Due to the intensification of violence in the country, the disbursement of the grant was terminated in late 2016 before most of the intended beneficiaries had accessed the grant. The study uses survey
\end{abstract}

data from face-to-face interviews and experimental data from lotteries, trust games, and a list experiment to assess the consequences of the cancellation in a comprehensive form. The empirical analysis employs instrumental variable regressions to control for individual characteristics that might have made it more likely to access the grant before disbursement was frozen. The results show that participants who received the originally planned treatment displayed significant improvements in their consumption, savings, and psychological well-being. However, participants who vainly expected to receive the cash grant showed reduced levels of consumption and women among this subgroup also experienced strong reductions in their trust level. In addition, the study finds some evidence that these women were less likely to migrate.

This paper is a product of the Poverty and Equity Global Practice and the Social Protection and Jobs Global Practice. It is part of a larger effort by the World Bank to provide open access to its research and make a contribution to development policy discussions around the world. Policy Research Working Papers are also posted on the Web at http://www.worldbank. org/prwp. The authors may be contacted at upape@worldbank.org and lralston@worldbank.org.

The Policy Research Working Paper Series disseminates the findings of work in progress to encourage the exchange of ideas about development issues. An objective of the series is to get the findings out quickly, even if the presentations are less than fully polished. The papers carry the names of the authors and should be cited accordingly. The findings, interpretations, and conclusions expressed in this paper are entirely those of the authors. They do not necessarily represent the views of the International Bank for Reconstruction and Development/World Bank and its affliated organizations, or those of the Executive Directors of the World Bank or the governments they represent. 


\title{
Broken Promises: Evaluating an Incomplete Cash Transfer Program
}

\author{
Angelika Müller, Utz Pape and Laura Ralston ${ }^{1}$
}

Keywords: unconditional cash transfers, trust attitudes, risk aversion, impact evaluation, violent conflict

JEL: C93, D13, D81

\footnotetext{
${ }^{1}$ Authors in alphabetically order. Corresponding authors: Utz Pape (upape@worldbank.org) and Laura Ralston (Iralston@worldbank.org). The authors are grateful for contributions from Mollie Foust, Luca Parisotto, Nadia Selim, Jeremy Shapiro and James Walsh as well as Nicola Pontara. We also thank Bledi Celiku, Axel Dreher, Arevik Gnutzmann-Mkrtchyan, Markus Goldstein and seminar participants at Heidelberg University and UC Davis for useful comments. The findings, interpretations and conclusions expressed in this paper are entirely those of the authors, and do not necessarily represent the views of the World Bank, its Executive Directors, or the governments of the countries they represent.
} 


\section{Introduction}

An increasing share of the world's poor live in fragile states, which poses new challenges to programs that seek to raise their incomes. One major risk associated with an insecure and fragile context is the unintended and unplanned interruption or cancellation of the program. Despite the prevalence of these cases, little is known about the effect of a program cancellation on intended beneficiaries. However, knowing about these risks would help policy makers make informed decisions about the costs and benefits of an intervention a priori. In addition, information on the consequences of failed implementation can help reduce detrimental impacts at the program design stage.

To our best knowledge, this study is the first to analyze what happens if an intended intervention is canceled. The Youth Startup Business Grant Program in South Sudan that was canceled due to erupting violence in 2016 provides us with the opportunity to study the impacts on socio-economic, behavioral and psychological outcomes on intended beneficiaries. In particular, we are interested in understanding effects on participants who were promised to receive a cash grant but did not ultimately receive it. Economic theory lends multiple reasons why outcomes for these participants could differ from outcomes in the absence of the program. Overall, our results suggest that the impact of failed interventions is mixed and depends on the gender of participants and their ex post treatment status. In this instance, on average across all participants, the invention was largely ineffective, but some subgroups were negatively affected. Given that applicants for the intervention were on average more educated than the average youth in South Sudan, the average population might have displayed reduced skills to cope with the program cancelation. In that sense, findings present a lower bound.

The Youth Startup Business Grant Program consisted of an unconditional cash grant combined with a business and life skills training exercise and was particularly targeted at young women. South Sudan has suffered from political instability and latent conflict since its inception in 2011. In this context, the youth struggled with declining livelihoods and a lack of economic opportunities. This put them at risk of participating or becoming victims of criminal or violent activities. Young women were at particular risk. In response, the program was designed by the World Bank in collaboration with the Ministry of Commerce to offer a cash grant worth US\$1,000. Existing evidence suggests that injections of capital are the most effective means of raising income in poor and fragile states (Blattman and Ralston 2015). Beneficiaries could access the grants denominated in local currency through a commercial bank account. Although the cash grant was aimed towards promoting (self-) employment and business development, beneficiaries were free to decide on its use. The program also entailed a one-week business and life-skill training, which participants needed to attend in order to access the grant. 
In late 2014 , the program randomly selected 1,200 beneficiaries out of a pool of more than 6,000 applications to receive the grant. More than 60 percent of the grants were awarded to young women. A similarly sized control group was selected to enable the assessment of the program in a rigorous impact evaluation. Baseline data from both treatment groups were collected before grant beneficiaries received their business and life skill training in April and May 2015. Almost all selected beneficiaries attended the 1-week training. After the training, participants were asked to open a commercial bank account in which the grant would be deposited.

Escalating violence at the end of 2015 forced the program to terminate the disbursement of the grants before all participants had accessed them. Completion of the program was first postponed and finally canceled to mitigate the perceived risk for beneficiaries to become the target of crime. In addition, there was the risk that the conflict might be exacerbated if grant money got into the wrong hands and was used to purchase arms. Delays in communication and in the processing of the grants meant that the timing at which disbursement was stopped varied across regions and bank branches.

Interventions in highly fragile and insecure states are often at risk of failing to be rolled out as originally planned. Obvious ethical objections make it impossible to study this effect in the form of a randomizedcontrolled trial. This study takes advantage of the circumstances under which the Youth Startup Business Grant Program was canceled to identify the socio-economic and behavioral consequences of projects that fail to be implemented as intended. Those originally assigned to the treatment group but who did not end up receiving grants show few systematic differences, except their location, from those who accessed the grants. We exploit this natural variation in location in interaction with the original assignment to the treatment group as an instrument for those who obtained the grants versus those who did not.

Hence, this study distinguishes between two de facto treatments. "Training but no grant" consists of having participated in the business skills training and been informed of receiving a US\$1,000 grant, but later having to experience that the grant disbursement was stopped. To assess the treatment effect, this group will be compared to the control group of the original intervention who was informed of not having been selected to receive the grant. In addition, this study analyzes the effect of the originally planned intervention. "Training and grant" consists of having participated in the life-skills training and successfully having accessed the cash grant.

On average, across all participants most socio-economic, and behavioral and psychological indicators were neither negatively nor positively affected by the intervention. However, when considering ex post treatment groups and gender, some groups were detrimentally affected by the intervention. For example, participants who only received the training, but expected the grant also, seem to have 
experienced small consumption declines relative to the control group. Female participants among this group also showed a strong reduction in their trust level. We also found some evidence that these women were less likely to migrate. Given that large shares of the population in South Sudan migrated in the period of our analysis to escape conflict affected areas, it is possible that women who expected the grant stayed back who would have migrated in the absence of the intervention. While we do not have direct information on this unintended consequence, one could be concerned of the potential detrimental outcomes to these participants.

Positive impacts were only detected on some outcomes and only to those who received the grants. For example, consumption, savings and reductions in debt, as well as reported levels of psychological well-being increased among the participants receiving both the training and the grant. These positive effects seemed to be independent of gender. Given these results, we argue that greater concern should be taken when planning programs in these volatile environments, as there is at least some evidence from our results on unintended negative consequences on program participants who did not receive the full set of benefits anticipated at the program outset.

The remainder of the paper proceeds as follows. Section 2 reviews theoretical considerations and the related literature. Section 3 discusses our study design. Section 4 describes our empirical specifications and discusses the reasoning behind our instrumental variable estimations. In Section 5, we describe the main results on the socio-economic, and the psychological and behavioral outcomes. Section 6 concludes.

\section{Theoretical considerations and existing literature}

The benefits of conditional cash transfers in non-fragile environments are well documented. For instance, multiple studies analyze the benefit of cash grants for education and health (see, Baird et al. 2014 and Manley, Gitter, and Slavchevska 2013 for systematic overviews). A large body of literature evaluates the benefits of cash grants for the profits and growth of microenterprises (Fafchamps et al. 2014; De Mel, McKenzie, and Woodruff 2008; Mel, McKenzie, and Woodruff 2012). More recent studies also document the benefits of cash transfers on self-employment and income. Banerjee et al. (2017) re-analyze results from six randomized trials on cash transfer program to show that cash grants do not discourage work as standard economic theory would suggest. In addition, Bianchi and Bobba (2013) find that a cash transfer program in rural Mexico significantly increased the probability to start an enterprise. Most relevant to our context, a study in the conflict-affected north of Uganda finds that a cash grant program targeted at generating self-employment among youth significantly increased their earnings (Blattmann, Fiala, and Martinez 2014). A recent analysis of an invention in Kenya also 
suggests that cash grant programs can have positive effects not only on the economic well-being of beneficiaries, but also on their psychological well-being (Haushofer and Shapiro 2016).

Despite the strong evidence on benefits of cash transfer programs, Baird, McKenzie, and Özler (2018) argue in their systematic literature review that "cash transfers that are made without an explicit employment focus [...] tend to result in little to no change in adult labor". To address this concern, the Youth Startup Business Grant Program in South Sudan combined the unconditional cash grant with a business skills training. Research on the impact of business trainings is generally mixed and the evidence is in the African context is scarce. An early study on microfinance clients in Peru found no economically significant effect of complementing a loan with a business training (Karlan and Valdivia 2011). In contrast, a randomized trial in India showed that business trainings could be effective in overcoming restrictions based on gender-norms that held female entrepreneurs back (Field et al. 2013). In addition, a study conducted in Ghana finds a rudimentary management training for micro and small enterprises can significantly improve their performance, because many business practices that are standard in developed countries are unknown to the participants (Mano et al. 2012). Furthermore, two studies on the same business training program for entrepreneurs in Tanzania both found that business knowledge significantly increased (Berge, Bjorvatn, and Tungodden 2014; Bjorvatn and Tungodden 2010). These diverging findings highlight that there is still a lack of evidence on the type of content that shows the best results (McKenzie and Woodruff 2014). In their meta-analysis on the effectiveness of entrepreneurship programs, Cho and Honorati (2014) find that business trainings are most effective among beneficiaries that already own a business and when combined with financial support.

Despite the extensive seminal work on cash grant programs and business skills trainings, the existing literature does not offer clear predictions on how beneficiaries are affected if a program has to be canceled. There are multiple reasons why the false expectation of receiving a cash grant could have detrimental effects on socio-economic outcomes. First, the existing literature on cash grants suggests that these are an effective way to overcome credit constraints. If beneficiaries commit to an investment in the belief to receive a grant in the future, it is likely to be welfare reducing if the grant disbursement never happens. Second, most seminal work on cash grants finds increases in consumption (See Baird, McKenzie and Özler 2018 for an overview of the literature). Again, if program participants already increase consumption before having accessed the grant, they might suffer from reductions in savings and consumption if their expectation does not come true. Finally, beneficiaries might decline employment opportunities that they would have accepted in the absence of the program. 
In addition, existing research lends multiple explanations of how the program cancellation might affect psychological and behavioral indicators. Psychological theory suggests that mental health depends strongly on external stressors as well as a person's resources to cope with these. Research on transfer program has shown that receiving grant payments can improve indicators of psychological well-being (Baird, de Hoop, and Özler 2013; Haushofer and Shapiro 2013; Ozer et al. 2011). Interestingly, Baird, de Hoop and Özler (2013) find also increased psychological distress among untreated study participants in treatment areas. These findings are consistent with the theory that psychological wellbeing depends on not only absolute economic status, but also relative economic status compared to one's peer group (Luttmer 2005). In consequence, it is likely that participants who knew about others who received the grant experienced a reduction in their personal utility. Recent evidence in experimental economics shows that the experience of being lied to significantly reduces participants' trust level as well as their trustworthiness (Gawn and Innes 2018). The "broken promise" that the cancellation of the program created could erode social capital in a similar way. Subsequently, other outcomes such as employment or engagement in crime and violence could suffer negative impacts. This mechanism would be particularly concerning, given new evidence that international organizations such as the World Bank sometimes enjoy more trust than governments - particularly if governments are seen as corrupt (Findley et al. 2017; Milner, Nielson, and Findley 2016). In addition, theory suggests particular risk for female participants. One study found that female transfer beneficiaries of the Oportunidades program in Mexico were more likely to receive violent threats from their partners, indicating that threats were used to extract rents (Bobonis, Gonzâlez-Brenes, and Castro 2013). Hence, there is a particular risk associated with the possibility that women who failed to access the grant could not convince their partners of the program cancellation. This might put them at increased risk to experience domestic violence. What is more, it is possible that the failed implementation influenced the migration decision of participants. Due to the conflict about a quarter of the South Sudanese population are currently internally displaced or have left the country. It is possible that the expectation of receiving the grant incentivized participants to stay back in their region of origin.

\section{Study Design}

The eligible population of the grant program was the youth in six states in South Sudan with focus on young women. The program was implemented in the least conflict-affected states in South Sudan at the time of its launch: Central Equatoria, Eastern Equatoria, Western Equatoria, Northern Bahrel Ghazel, Western Bahrel Ghazel, Lakes State. Eligible individuals had to be aged between 18 and 34 and be of South Sudanese nationality. Originally, 200 individuals were selected from each of the six states. A share of 60 percent of the grants was targeted at women. 
The program received approximately 6,000 applicants. Interested applicants had to submit a one-page written proposal for a new business idea. The document had to be written in English, although communication materials were also provided in Juba Arabic. In addition, the applications required proof of their South Sudanese nationality and documents needed to open a bank account. This application process was designed to incentivize positive self-selection into the sample. In this sense, the program participants may be better equipped to use the cash grant successfully to improve their business or employment situation than the average population. From the received 8,240 applications, 4,699 were found to be eligible. ${ }^{2}$ From these eligible applicants, 1,200 were randomly selected to receive the grant and 1,200 were randomly selected for study in the control group, with equal proportions per state and by gender. The baseline survey was conducted between January to March 2015 and data were collected from 1,144 treatment participants and 1,148 control participants. Approximately 4.5 percent of initially identified study participants could not be tracked and did not participate in either the baseline survey or the program. The baseline survey was concluded prior to the commencement of the one-week training that was held across the 6 states between April and May 2015.

Figure 1 Treatment streams of original and new intervention.

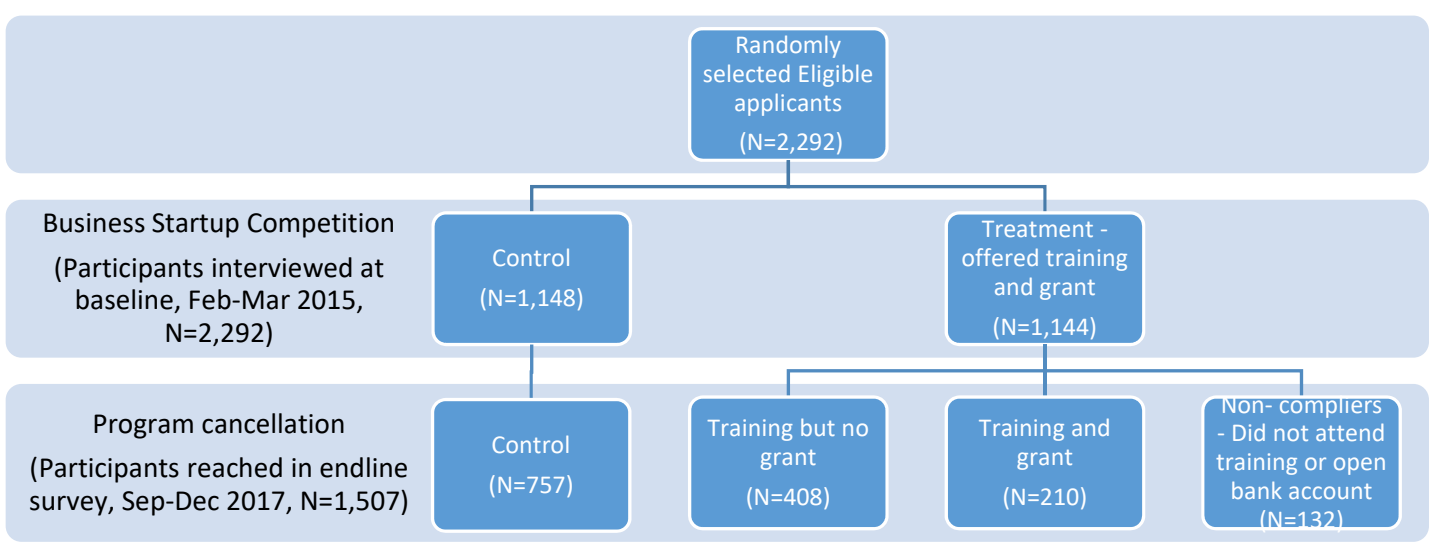

The intensification of violence between 2015 to 2017 forced many study participants to migrate reducing the number of participants that could be located for the endline survey. About a quarter of the population of South Sudan was displaced during the study period, which made it difficult to locate all participants of the original control and treatment group. Before the endline survey, the World Bank

${ }^{2}$ Of those deemed ineligible, the desired purchase of land was the main reason. Other explanations included blank or unrealistic business ideas, age listed outside target range (18-35 years), no identification attached, or not being South Sudanese. 
conducted a phone survey in May 2017 that informed the grant beneficiaries of the halt of the program and assessed the feasibility of collecting endline data. The phone survey managed to reach around 55 percent of the study participants (1,264: 642 from the control group and 622 from the original treatment group), from which 99 percent agreed to participate in the endline.

Due to budget and logistical considerations, the endline survey targeted a sample size of 1,800 individuals randomly chosen from the list of participants after prioritizing the phone survey respondents who had agreed to be interviewed again. Endline data collection activities commenced in September 2017. After intensive tracking efforts over a period extending to four months, ${ }^{3} 1,524$ participants were located, and 1,507 participants completed the interviews. The respondents interviewed in the endline survey were given the opportunity to voice their concerns and opinions about the cash grant program, through short video testimonials that are publicly available online. ${ }^{4}$ Out of these 1,507 respondents, 1,045 had been reached in the phone survey and 462 had been located through intensive tracking efforts based on information provided in the baseline. ${ }^{5}$ Figure 2 illustrates the time line of the data collection and intervention steps.

Figure 2 Timeline of program implementation, cancellation and data collection

\begin{tabular}{|c|c|c|c|c|c|c|c|}
\hline $\begin{array}{l}\text { Dissemination, } \\
\text { and Marketing } \\
\text { Campaign } \\
\end{array}$ & $\begin{array}{c}\text { Baseline } \\
\text { survey } \\
\vdots \\
\vdots\end{array}$ & $\begin{array}{l}\text { 1-week } \\
\text { business } \\
\text { and life } \\
\text { skill } \\
\text { training } \\
\text { Opening of bank } \\
\text { accounts }\end{array}$ & & $\begin{array}{c}\text { Conflict Cancellation } \\
\text { escalation of program } \\
\qquad \begin{array}{l}\text { Freezing of } \\
\text { disbursement }\end{array} \\
\text { d }\end{array}$ & $\begin{array}{c}\text { Phone } \\
\text { survey } \\
\vdots \\
\vdots\end{array}$ & $\begin{array}{c}\text { Endline } \\
\text { survey } \\
\vdots\end{array}$ & \\
\hline 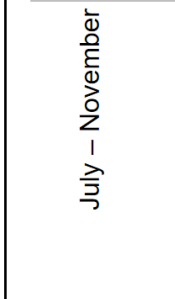 & 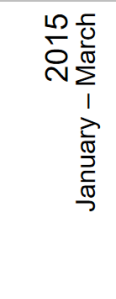 & $\begin{array}{l}\frac{\vec{\pi}}{\sum^{2}} \\
\frac{1}{\bar{\Sigma}} \\
\frac{0}{2}\end{array}$ & $\stackrel{\bullet}{\frac{N}{\delta}}$ & 승 & 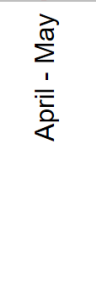 & 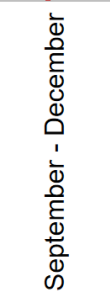 & $\stackrel{\infty}{\infty}$ \\
\hline
\end{tabular}

\footnotetext{
${ }^{3}$ The majority of data was collected between September to November 2017, but field teams remained on the ground until end of December 2017 trying to locate and interview participants.

${ }^{4}$ The video testimonials from the BSCIE as well as other surveys conducted in South Sudan during this period are available at: www.thepulseofsouthsudan.com

${ }^{5}$ Intensive tracking efforts included returning to the GPS coordinates for the baseline survey and looking for participants, contacting other contacts listed by the participant in their program application and through the baseline survey, asking other respondents, local officials, at the Chambers of Commerce and trade unions about the location of difficult to find participants, and making at least five attempts to find persons over a period of several weeks.
} 
At the end of the endline survey, there was approximately equal representation between the treatment (750) and control (757) groups, with 394 and 391 fewer observations from each group respectively. This was despite ongoing conflict keeping enumerators from going to a few counties due to insecurity. ${ }^{6}$ As a robustness check on results, the difficult-to-reach study participants (those reached only through intensive tracking) are reweighted to regenerate the baseline sample. This recognizes that the hard-to-reach may be more representative of the outstanding missing observations in the endline data than those reachable through the phone survey.

The main approach for measuring outcome variables was through face-to-face interviews that were conducted as part of baseline and endline surveys described above. In addition, risk preferences, trust attitudes and engagement in crime and violence were assessed using experimental data collected during these face-to-face interviews from decisions reported over lotteries, trust games and elicited through list experiments (see appendix 1 for full methodological details).

The hypotheses of this study are grouped into 2 main families of outcomes - socio-economic outcomes, and psychological and behavioral outcomes. It is possible that these families of outcomes were differently affected by the intervention. For instance, it is possible that participants who failed to access the grant but participated in the training did not experience any negative effects on their socioeconomic situation while suffering negative effects on their psychological and behavioral well-being. Table 1 Main outcomes of interest provides detailed information on the individual outcomes we studied in each category.

\section{Methodology}

\subsection{Selection into treatment arms}

Selection into treatment arms was a two-stage process. In the first stage participants from the control group and the original treatment group were randomly selected according to the originally planned experiment. A balance test on these baseline study participants shows no systematic differences between the original control and the treatment groups (Table2). We find weak evidence that the control group was slightly less affected by the conflict. Our measure of conflict exposure is based on geo-referenced data by UCDP (Sundberg and Melander 2013). It consists in an average of deaths by event within a $300 \mathrm{~km}$ radius weighted by geographic proximity to participants' baseline location. ${ }^{7}$

\footnotetext{
${ }^{6}$ In WEQ: Mvolo, Mundri East, and Mundri West ; in CEQ: Kajo Keji, Morobo, and Lainya ; in Lakes: Rumbek North (flooding during time of data collection).

${ }^{7} 300 \mathrm{~km}$ equals the maximum distance of any program participants to a KCB bank branch. We also tested $50 \mathrm{~km}$, $100 \mathrm{~km}, 200 \mathrm{~km}$ radii, but the results remain extremely similar.
} 
Figure A6.2 in the appendix displays maps of conflict events before program initiation and between baseline and endline survey. The difference in conflict exposure between control and treatment group is only significant at the $90 \%$ level. To control for potential selection bias, we include conflict exposure as control variable in our regressions. In addition, we find no evidence that attrition depended on the selection of the original treatment group (Appendix table A1.1), nor differential attrition across covariates between these two groups (Appendix table A1.3). ${ }^{8}$ Importantly, there is also no evidence that participants in the control group accessed either the training or the grants. What is more, the low geographic concentration of program participants makes spill-over effects unlikely. Hence, control group outcomes can plausibly be regarded as counterfactual outcomes for beneficiaries in the absence of the program.

The second stage of the selection process decided which de facto treatment participants of the original treatment group received. Since the cancellation of the program was not planned, this process was not systematically controlled. Among the original treatment group participants reached through the endline survey, we have three de facto groups. The "Training but no grant" group consists of the 408 individuals that had not accessed their grants when erupting violence forced the program to terminate in late 2015, the "Training and grant" group consists of the 210 individuals who successfully accessed the grant, and the "Non-compliers" group consists of 132 individuals who did not attend the training and therefore could not access the grant. ${ }^{9}$ The assignment process to these de facto treatment arms poses some challenges for identification. Participants had no reason to anticipate that the grant disbursement might be frozen in the future, the assignment to "Training and grant" and "Training, but no grant" was partly random. However, participants who tried to access the grant right after the training had a higher chance of receiving it than those who waited, so individual characteristics of the participants might have created some self-selection into these two groups.

To assess the degree of endogenous selection into the "training but no grant" and "training and grant" groups, we examine the balance on covariates between these two groups using the baseline data. We find that older, married participants with larger families were more likely to access the grants (see Table 3). In addition, participants who received the grant were more likely to already own a business and hold a bank account, reported higher consumption levels and reached higher ranks in our literacy

\footnotetext{
${ }^{8} \mathrm{~A}$ further balance test between attritors and non-attritors from the overall study showed some systematic differences (Appendix table A1.2): at the 1 percent significance level attritors were less likely to hold a formal bank account at baseline and had a lower educational level, and at the 5 percent significance level attritors had a lower food consumption, less formal and more informal debt, and came from smaller households with fewer children. We control for these differences as additional covariates in our regressions.

${ }^{9}$ Attending the training program was a pre-requisite to accessing the grant. Part of the training included financial literacy around opening and using the bank accounts, so only those participating had bank accounts opened for them.
} 
and numeracy evaluations. Hence, there is some evidence that those who accessed the grants were endogenously equipped to have better access to grants (via prior formal banking experience) or predisposed to benefit more greatly from them in terms of the socioeconomic outcomes we measured. Therefore, when analyzing the treatment effects the estimations will address endogenous selection into training and grants group not only by the inclusion of covariates, but also with an instrumental variable approach that focuses on an exogenous channel through which some participants were better enabled to access the grants. Importantly, we do not find strong evidence that exposure to conflict events determined whether participants could access the grant or not.

Despite some correlations with individual covariates as discussed above, the main determinant whether participants had access to the grant was their location. In Lakes and Western Bahr El Ghazal the majority of the eligible participants received the cash grants, while in Eastern Equatoria and Western Equatoria the majority did not receive the grants (Table 3). The difference between states can be explained by failures in the coordination between different bank branches across the six states. While some branches moved quickly with halting disbursements of grants, other branches did not. In addition, selection into de facto treatment arms depended on the distance to the closest KCB bank branch. Figure A6.1 in the appendix displays participants' baseline location, major cities in the project states and locations of KCB bank branches. Since not every large city in South Sudan had a branch of this particular bank, we regard this variable as plausibly exogenous and exploit it for an instrumental variable approach.

\subsection{Estimation strategy}

We begin our analysis by estimating an intent-to-treat effect which gives us the average effect of the intervention on all participants that were selected for the original treatment group. Since assignment to the original treatment group was randomized the coefficient of the estimate has a causal interpretation. It tells us whether there was a negative net average effect of the intervention on any of the main outcomes. This gives us a first indication of whether the intervention created more "harm" than "good". The specification for the intent-to-treat effect is as follows:

(1) $y_{i j}=\beta Z_{i}+X_{i}^{\prime} \gamma+s_{j}+\varepsilon_{i j}$

where $y_{i t}$ is a vector of outcomes for individual $i$ in strata $j, Z_{i}$ is a dummy variable that takes a value of 1 if individual $i$ was originally selected for the cash grant program, $s_{j}$ are strata fixed effect and $\varepsilon_{i j}$ is the error-term clustered at baseline boma level. $X_{i}^{\prime}$ are individual-level covariates that were collected at baseline and might affect outcome variables. In addition, we run treatment-on-the-treated (TOT) estimations to understand the effects of receiving "Training and grant" or "Training, but no grant". The specification for the treatment-on-the-treated effect is as follows: 
(2) $y_{i j}=\alpha$ Treatment $1_{i}+\beta$ Treatment $2_{i}+X_{i}^{\prime} \gamma+s_{j}+\varepsilon_{i j}$

where $y_{i t}$ is a vector of outcomes for individual $i$ in strata $j, s_{j}$ are strata fixed effect, $X_{i}^{\prime}$ are individuallevel covariates that were collected at baseline, $\varepsilon_{i j}$ is the error-term clustered at boma level, Treatment $1_{i}$ is a dummy variable that takes a value of 1 if individual $i$ participated in the business skills training, but did not receive the grant due to the cancellation of the program and Treatment $2_{i}$ is a dummy variable that takes a value of 1 if individual $i$ participated in the training and also received their grant. Thus, participants that received no treatment because they were either part of the control group or were invited but did not attend the training build the baseline of this estimation. TOT effects of treatment 1 and treatment 2 are estimated by parameters $\alpha$ and $\beta$ respectively. As discussed above, the treatment-on-the-treated effects has no causal interpretation, because participants assignment to "training, but no grant" and "training and grant" partly depended on the time at which participants tried to access the grant as well as willingness to attend the training and could therefore be endogenous.

To address endogenous selection into "training and grant" versus "training, but no grant", we run instrumental variable regressions. As described previously, the instrumental variable relies on the fact that receiving the grant was conditional on holding a formal bank account at KCB bank. KCB bank operated only 16 bank branches in that time in South Sudan, out of which 15 were in the states of our program. A KCB bank branch was not in every large city. This leads to some variation in how convenient it was to access the grant which is uncorrelated with participants' personal characteristics. Of course, the distance to the closest KCB bank branch may correlate directly with many other geographic variables that affect our outcomes. Fortunately, we also have observations from the control group, that was randomly selected, and can therefore control for outcome differences conditional on the distance to the closest bank branch. To do so, we interact the logarithmic distance to the closest KCB bank branch with a dummy variable that marks the original assignment to the treatment group. The local average treatment effect (LATE) then estimates the effect of having received training and grant, because one was selected for the original treatment group and lived close to a KCB bank branch while controlling for the average outcome levels at the location.

Our first stage regressions in Table 7 demonstrate that even after controlling for distance to the closest KCB branch the interaction term remains a strong predictor of whether participants received "training and grant" or "training, but no grant". In addition, we argue that the instrument is excludable. We exploit the variation generated through the interaction between distance to the closest KCB branch and exogenous assignment to the treatment group, while controlling for the main effect of the potentially endogenous distance to closest KCB branch. This interaction term can be considered an 
exogenous regressor under some mild assumptions (Bun and Harrison 2018). ${ }^{10}$ The exclusion restriction requires that conditional on the distance to the closest KCB branch the instrument affects outcomes not directly, but only by making it more or less likely that a participant will receive the grant. It would only be violated if the interaction term had a direct effect on outcomes, i.e. if being selected for the treatment group had different effects for participants closer to a KCB branch that did not result from a higher probability to receive the grant. We do not think this is plausible.

The specification for the local average treatment effects are as follows.

Second stage equation:

(3) $y_{i j}=\alpha$ Treatment $1_{i}+\beta$ Treatment $2_{i}+\delta K C B$ Distance ${ }_{i}+X_{i}^{\prime} \gamma+s_{j}+\varepsilon_{i j}$

First stage equations:

(4a) Treatment $_{i}=\alpha Z_{i}+Z_{i} \times K C B$ Distance $_{i}^{\prime} \sigma+\delta K C B$ Distance $e_{i}+X_{i}^{\prime} \gamma+s_{j}+\varepsilon_{i j}$

(4b) Treatment $2_{i}=\alpha Z_{i}+Z_{i} \times K C B$ Distance ${ }_{i}^{\prime} \sigma+\delta K C B$ Distance ${ }_{i}+X_{i}^{\prime} \gamma+s_{j}+\varepsilon_{i j}$

where $y_{i t}$ is a vector of outcomes for individual $i$ in strata $j, s_{j}$ are strata fixed effect, $X_{i}^{\prime}$ are individuallevel covariates that were collected at baseline, $\varepsilon_{i j}$ is the error-term clustered at boma level, and Treatment $1_{i}$ and Treatment $2_{i}$ are dummy variables indicating treatment streams as described above. Equations (4a) and (4b) display the first-stage equations, which instruments Treatment $1_{i}$ and Treatment $2_{i}$ with the original assignment to treatment $Z_{i}$ as well as the interaction between $Z_{i}$ and the logarithmic distance to the closest KCB branch KCB Distance ${ }_{i}$. Like the TOT estimation, the LATE of treatment 1 and treatment 2 will be estimated by parameters $\alpha$ and $\beta$ respectively.

In addition, we establish a separate method to estimate experimental data on sensitive outcomes that tend to be under-reported when asked about directly through survey data. For example, we used list experiments to collect information on conflict and crime. The list experiment relies on a separate treatment group to assess the true propensity of positive answers in the study population. As we are not only interested in the propensity of positive answers in average across all study participants but would like to know whether participation in either treatment group changed the propensity of positive responses, we deploy a difference-in-difference estimation. This estimator calculates the difference in positive responses between positive responses in the control group and treatment group. It consists

\footnotetext{
${ }^{10}$ In particular, the identifying assumption is that the outcome variables and the endogenous variable distance are jointly independent of the exogenous variable of original treatment assignment (Angrist and Krueger 1999, $\sec 2.3 .4)$.
} 
of an interaction between treatment status of our invention and treatment status in the list experiment. While list experiments often use simple difference-in-means estimators, it can be useful to use regression in order to control for covariates (Imai 2011). In favor of simplicity, this study opts for a linear regressor with an interaction between original intervention and list experiment treatment (Blair and Imai 2017). This allows us to estimate not only the intent-to-treat effect, but also the local average treatment effect, similar to the estimation strategy used for other indicators.

Outliers and indicators with limited variation were excluded from the final sample. In order to exclude outliers, indicators were winsorized all continuous non-negative indicators at 99 percent at the topend. In addition, indicators were tested for limited variation as determined by the pre-analysis plan. This implied that questions for which 95 percent of observations have the same value within the relevant sample were omitted from the analysis. This resulted in the exclusion of only 6 indicators. ${ }^{11}$

The exploratory nature of this study makes it necessary to test a large number of outcomes. However, testing a multitude of hypotheses makes it more likely to identify an effect in any one of the outcomes. To control for this type of bias the study uses two approaches. First, the number of tested hypotheses is reduced by summarizing outcome variables into grouped indices. To create indices, we combine indicators related to each primary group of outcomes, by creating standardized indexes following a method championed by Anderson (2008) and Haushofer and Shapiro (2016). The indexes consist of a weighted average of a number of standardized outcome variables within a outcome group, e.g. employment or consumption. Weights are calculated by the inverse of the covariance matrix of outcomes within one group. This approach maximizes the variance of the final index (See Appendix 5). It allows us to keep the number of outcome variables low and allow for greater statistical power. Since combining individual outcome variables in indexes as described above still leaves multiple groups or families of key outcomes of interests, regressions also report p-values adjusted by false discovery rate following the two-step procedure introduced by Benjamini and Hochberg (1995). ${ }^{12}$ It controls for the expected proportion of rejections that are type I errors within a family of outcomes. The group of socio-economic and behavioral/psychological outcomes are employed as the two main families of outcomes.

\footnotetext{
11 Indicators excluded due to limited variation are: Engagement in cattle raids and frequency of cattle raids, number of times having been beaten during the past month, in-kind payment for wage employment, remaining amount from a formal loan and remaining amount from an informal loan.

${ }^{12}$ See also Anderson (2008) for a discussion of adjusting p-values by controlling for false discovery rate versus controlling for family-wise error rate.
} 
In addition, we include an analysis on gender heterogeneity. We split the sample across gender and report all estimates for both subsamples separately. We also test whether male and female point estimates are significantly different by means of a Wald-test. The gender analysis can be found in Appendix 3.

\section{Results}

\subsection{Socio-economic outcomes}

The intervention had no effect on employment. Study participants showed no positive improvement in the employment index on average (Table 5). What is more, none of the estimators that differentiate between the two ex post treatments reach conventional levels of statistical significance (Table 8). When looking at gender heterogeneity, the treatment-on-the-treated estimates show a statistically significant improvement of the employment indicator of about 0.3 standard deviations for female participants over male participants in either treatment group (Table A3.3). These findings are consistent with the idea that the 1-week business skills training - in which both treatment groups participated - was particularly effective for women. However, the 2SLS results are weaker. Although the coefficients are large and positive for both female ex post treatment groups, large standard errors keep the estimates from reaching the 10 percent significance level.

For the consumption indicator we find no impact, on aggregate (Table 5). Once we control for selection into the two ex post treatments, we find a large (up to 1 standard deviation) and statistically significant increase in consumption for participants that received both training and grant (Table 8). This effect matches findings of existing literature on cash grants that typically find large consumption effects (e.g. Haushofer and Shapiro 2016; Manley, Gitter, and Slavchevska 2013). The pattern is consistent across genders and point estimates are not significantly different between male and female participants (Table A3.3). Furthermore, participants that only received the training, but expected the grant also, seem to have experienced small consumption declines relative to the control group. These findings suggest that grant money was partly used to boost consumption, while unexpectedly not receiving the grant had a negative impact on this measure of welfare.

The intention-to-treat estimates indicate a positive aggregate impact of the program on the savings indicator (Table 5). However, when we analyze the different ex post treatments, we can see a positive impact only for those who received training and grants (Table 8). The effect is large at up to about 1 standard deviation and significant at the 1 percent level. The gender analysis shows the same trend for males and females (Table A3.3). Although males display a slightly larger point estimate, the difference is not significant. This finding is again in line with existing evidence on the effects of cash transfers (e.g. Banerjee et al. 2015). 
Business skills did not improve on aggregate (Table 5). The results provide some evidence that skills improved for those that were able to access the grants when calculated as a treatment-on-the-treated effect. When we control for self-selection through the LATE, the effect becomes close to zero and statistically insignificant (Table 8). This suggests that business skills improved only for participants who had already a greater propensity to benefit from the intervention and were more likely to receive the grant due to their personal characteristics (e.g., higher business savviness).

\subsection{Psychological and behavioral outcomes}

Turning to psychological well-being, the results display no impact of the intervention on average (Table 6). Yet, when looking at the differences between the two ex post treatments, the LATE estimate shows a statistically significant increase of about 0.8 standard deviations in this indicator for participants that received both training and grant (Table 9). This result echoes new findings on the psychological benefits of cash transfers (Haushofer and Shapiro 2016; Ozer et al. 2011). Importantly, we find no significant increase for participants that went to the training but were not able to access the grant (Table 9). While statistically insignificant both the TOT and the LATE estimates for this group show positive point estimates. Therefore, it appears very unlikely that the program negatively affected psychological well-being as suggested by literature on relative economic status and well-being (Luttmer 2005). Possibly participants of the "training and grant" group still perceived themselves relatively well-off compared to their peer-group because they had the chance to participate in the business-and-life skills training. We also find no significant difference between genders (Table A3.4).

For risk preferences, the results draw a similar picture. While there is no effect on risk preferences on average (Table 6), according to the LATE estimates risk preferences increased by about 0.7 standard deviations for participants that got training and grant (Table 9). Still, this result should be interpreted cautiously, since it reaches only the 10 percent significance level. Again, there seems to be no large difference in the effect on male or female participants (Table A3.4),

The trust indicator is another indicator where we find a negative impact of the program cancellation. Although there is no effect on trust on the average treatment group participant (Table 6), participants who received the training, but were not able to access the grant, show a reduction in trust by about 0.5 standard deviation (Table 9). The effect seems to be driven by female participants. While male participants of both ex post treatments display positive insignificant effects, female participants who failed to access the grant show a highly significant reduction in their trust indicator by about 0.9 standard deviation (Table A3.4). Surprisingly, women who also received the grant as well as the training display a negative LATE estimate, although this result is only significant at the 10 percent level. This empirical finding is consistent with two alternative theoretical explanations. First, this could echo the findings of Gawn and Innes (2018) from the lab that the experience of being lied to erodes trust. An 
alternative explanation suggested by the literature would be that cash transfers put women at increased risk of violent threats which in turn reduces their general trust level. The latter explanation could also account for the fact that reductions in trust levels were experienced by both women who received the grant and those who failed to receive it.

The effect on crime and violence is complex. On average, the results show a weakly significant negative effect on the crime and violence indicator (Table 6), indicating lower levels of vulnerability to crime and violence and lower participation in security groups. Turning to the two ex post treatments, some of the LATE estimates suggest a weakly significant negative effect on participants that received the training, but not the grant (Table 9). This pattern can also be found in the female sub-sample, not, however, in the male (Table A3.4). Yet, the most rigorous specification fails to reach the 10 percent significance level. On net, it does not seem that the intervention had impacts on these measures of crime and violence.

We find no significant effect on migration propensity either on average (Table 6) or among both ex post treatment groups (Table 9). For female participants, we find some evidence that those who failed to access the grant are slightly less likely to migrate (Table A3.4). Again, the most rigorous specification, however, falls short of reaching the 10 percent significance level.

Finally, turning to results of the list experiment, there seems to be on average a slight increase in the propensity of cattle raiding, but not in aggressive arguments (Table 6). In particular, the increase in cattle raiding is prominent among the group that did not receive the grant (Table 9). However, after controlling for self-selection into this group through the LATE estimates, the effect becomes smaller and loses statistical significance. It is likely the effect is not causally driven by the disappointment of not receiving the grant or whether this group was initially more likely to engage in cattle raiding. When observing differences across genders we even find weak evidence that cattle raiding increased among men that received both the training and the grant (Table A3.4). In contrast, aggressive arguments seem to have fallen among participants that received only the training, but not the grant (Table 9). Altogether, it is difficult to determine a strong impact of the intervention on the propensity to engage in cattle raiding or aggressive arguments.

\subsection{Robustness}

Since our study showed some degree of attrition, we test the robustness of our ITT estimates by calculating upper and lower bounds following Lee (2008). These correct for attrition by making the extreme assumption about missing information. We report the results in Appendix 2. Even after extreme assumptions about attritors the ITT effect on the savings, investment and debt index remains statistically significant - overall, savings increased among those assigned to receive training and grants 
by about 0.3 standard deviations. In contrast, the crime and violence index loses its significance when assuming that attritors reached higher values of the outcome distribution. Nevertheless, the effect size does not change much which makes us confident that estimated reduction is not an artifact of the data selection.

In addition, we address potential attrition bias by re-weighting observations based on their likelihood to be included in the final sample. Control group participants that were reached during the phone survey had an 82 percent likelihood to be reached for the final survey, while control group participants that were not reached during the phone survey had only a 46 percent likelihood to be reached for the final survey. Likelihoods to be reached in the final survey differ similarly for the treatment group. We thus attach sampling weights to all observations based on the inverse likelihood to be successfully interviewed for the final survey. Results are reported in Tables A2.3 to A2.6.

All intention-to-treat estimates proof robust to our re-weighing exercise. The weighted regressions confirm a positive average effect on the savings, investment and debt index, a negative effect on the likelihood to be vulnerable to crime and violence, and a positive effect on the list experiment on cattle raiding.

Turning to results that distinguish between "training and grant" and "training, but no grant" largely confirm our main results. Our main results show positive effects on consumption and savings for participants that received training and grant, and this finding is confirmed in the weighted regressions. What is more, the weighted regressions confirm our positive finding on the effect of grant and training on psychological well-being. For participants that only received the training, but not the grant, we can also confirm that estimates on trust, on crime and violence and on the list experiment regarding aggressive arguments show a weakly significant negative effect.

\section{Conclusion}

Our study used the example of the unplanned cancellation of the South Sudan Youth Business StartUp Grant Program to evaluate the impacts of interventions that fail to be implemented as planned. Overall, our results suggest that the impact of failed interventions is mixed and depends on the gender of participants and their ex post treatment status. In this instance, on average across all participants, the intervention was largely ineffective. Most socio-economic or psychological and behavioral indicators neither worsened nor improved.

However, when considering ex post treatment groups and gender, some groups were detrimentally affected by the intervention. In particular, female participants that had expected to receive the cash grant but did not due to the cancellation of the program showed a strong reduction in their trust level. We also found some evidence that these women were less likely to migrate. Given that large shares of 
the population in South Sudan migrated in the period of our analysis to escape conflict affected areas, it is possible that women that expected a grant stayed back in expectation of the grant that would have migrated in the absence of the intervention. While we do not have direct information on this unintended consequence, one could be concerned regarding the potential detrimental outcomes to these program participants.

Where positive impacts were detected, for example on savings and on consumption, these tended to accrue to those that received the grants. Although the group that received the grant was smaller than the group that only received training, the positive impacts on the savings indicator was large enough to lift the average effect above a statistically significant level, but not for the consumption indicator. In addition, psychological well-being improved for the group receiving both training and grants. These positive effects seemed to be independent of gender.

The most unexpected result is the reported reduction of crime and violence experienced by women who did not receive the grant. Equally puzzling is the reduction in aggressive arguments among both men and women of the group who did not receive the grant money. Potentially this finding is due to a reporting bias on this indicator. For example, those who did not receive the grant but had expected to, became more wary about reporting on sensitive events, given that they may have perceived the program to be less responsive to their needs and vulnerabilities.

This paper is the first study that shows how failed intervention can have a negative impact on intended beneficiaries. While we did not identify clear socio-economic disadvantages for participants that vainly expected to receive the grant money, the negative impact on female trust levels and migration behavior should warn policy makers to pay more attention to unintended damage from failed interventions. Since the main negative effect appears only for the female subgroup, the external validity of the result should be confirmed by further research on failed inventions and heterogenous effects across gender. Although most indicators showed no significant net improvements, participants who did receive the treatment as intended seemed to benefit economically and psychologically. While it remains to be argued whether these positive impacts outweigh the negative impacts on participants who did not receive the complete treatment, our study makes it clear that interventions should consider the consequences of potential failure in the planning stages. For example, future interventions in risky environments might want to explicitly flag the potential of a program cancellation to pro-actively mitigate against trust loss. 


\section{References}

Andreoni, James, and Charles Sprenger. 2010. "Certain and Uncertain Utility: The Allais Paradox and Five Decision Theory Phenomena." Levine's Working Paper Archive: 1-21. http://citeseerx.ist.psu.edu/viewdoc/download?doi=10.1.1.193.836\&rep=rep1\&type=pdf.

Angrist, Joshua D., and Alan B. Krueger. 1999. "Empirical Strategies in Labor Economics." In Handbook of Labor Economics Vol. 3, eds. Orley C. Ashenfelter and David Card. Amsterdam: Elsevier, 12771366.

Baird, Sarah, Francisco H.G. Ferreira, Berk Özler, and Michael Woolcock. 2014. "Conditional, Unconditional and Everything in Between : A Systematic Review of the Effects of Cash Transfer Programs on Schooling Outcomes." Journal of Development Effectiveness 6(1).

Baird, Sarah, Jacobus de Hoop, and Berk Özler. 2013. "Income Shocks and Adolescent." The Journal of Human Resources 48(2): 370-403.

Baird, Sarah, David McKenzie, and Berk Özler. 2018. 8404 Policy Research Working Paper The Effects of Cash Transfers on Adult Labor Market Outcomes.

Banerjee, Abhijit et al. 2015. "A Multifaceted Program Causes Lasting Progress for the Very Poor: Evidence from Six Countries." Science 348(6236).

Banerjee, Abhijit V., Rema Hanna, Gabriel E. Kreindler, and Benjamin A. Olken. 2017. "Debunking the Stereotype of the Lazy Welfare Recipient: Evidence from Cash Transfer Programs." World Bank Research Observer 32(2): 155-84.

Benjamini, Yoav, and Yosef Hochberg. 1995. "Controlling the False Discovery Rate: A Practical and Powerful Approach to Multiple Testing." Journal of the Royal Statistical Society 57(1): 289-300.

Berg, Joyce, John Dickhaut, and Kevin McCabe. 1995. "Trust, Reciprocity, and Social History." Games and Economic Behavior 10: 122-42.

Berge, Ivar Lars Oppedal, Kjetil Bjorvatn, and Bertil Tungodden. 2014. "Human and Financial Capital for Microenterprise Development: Evidence from a Field and Lab Experiment." Management Science.

Bianchi, Milo, and Matteo Bobba. 2013. "Liquidity, Risk, and Occupational Choices." The Review of Economic Studies 80(2): 491-511.

Bjorvatn, Kjetil, and Bertil Tungodden. 2010. "Teaching Business in Tanzania: Evaluating Participation and Performance." Journal of the European Economic Association 8(2): 561-70.

Blair, Graeme, and Kosuke Imai. 2017. "Statistical Analysis of List Experiments." Political Analysis 20(1): 47-77.

Blattman, Christopher, and Laura Ralston. 2015. "Generating Employment in Poor and Fragile States: Evidence from Labor Market and Entrepreneurship Programs." SSRN Electronic Journal. http://www.ssrn.com/abstract=2622220.

Blattmann, Christopher, Nathan Fiala, and Sebastian Martinez. 2014. "Generating Skilled SelfEmployment in Developing Countries: Experimental Evidence from Uganda." The Quarterly Journal of Economics: 697-752.

Bobonis, Gustavo J., Melissa Gonzâlez-Brenes, and Roberto Castro. 2013. "Public Transfers and Domestic Violence : The Roles of Private Information and Spousal Control." American Economic Journal: Economic Policy 5(1).

Bun, Maurice J. G., and Teresa D. Harrison. 2018. "OLS and IV Estimation of Regression Models 
Including Endogenous Interaction Terms." Econometric Reviews: 07474938.2018.1427486. https://www.tandfonline.com/doi/full/10.1080/07474938.2018.1427486.

Cho, Yoonyoung, and Maddalena Honorati. 2014. "Entrepreneurship Programs in Developing Countries: A Meta Regression Analysis." Labour Economics 28: 110-30. http://dx.doi.org/10.1016/j.labeco.2014.03.011.

Fafchamps, Marcel, David McKenzie, Simon Quinn, and Christopher Woodruff. 2014. "Microenterprise Growth and the Flypaper Effect: Evidence from a Randomized Experiment in Ghana." Journal of Development Economics 106: 211-26. http://dx.doi.org/10.1016/j.jdeveco.2013.09.010.

Field, Erica et al. 2013. "Do Traditional Institutions Constrain Female Entrepreneurship ? A Field Experiment on Business Training in India." American Economic Review: Papers \& Proceedings 100(2): 125-29.

Findley, Michael G., Adam S. Harris, Helen V. Milner, and Daniel L. Nielson. 2017. "Who Controls Foreign Aid? Elite versus Public Perceptions of Donor Influence in Aid-Dependent Uganda." International Organization (October 2015): 1-31. https://www.cambridge.org/core/product/identifier/S0020818317000273/type/journal_article.

Gawn, Glynis, and Robert Innes. 2018. “Do Lies Erode Trust?" International Economic Review 59(1): 137-61.

Haushofer, Johannes, and Jeremy Shapiro. 2013. "Household Response to Income Changes: Evidence from an Unconditional Cash Transfer Program in Kenya." Massachusetts Institute of Technology 24(5): 1-57.

Haushofer, Johannes, and Jeremy Shapiro. 2016. "The Short-Term Impact of Unconditional Cash Transfers to the Poor: Experimental Evidence from Kenya." The Quarterly Journal of Economics 131(4): 1973-2042.

Imai, Kosuke. 2011. "Multivariate Regression Analysis for the Item Count Technique." Journal of the American Statistical Association 106(494): 407-16.

Jakiela, Pamela, and Owen Ozier. 2015. "The Impact of Violence on Individual Risk Preferences: Evidence from a Natural Experiment." World Bank Policy Research Paper (9870). http://search.ebscohost.com/login.aspx?direct=true\&db=psyh\&AN=2015-16847-

001\&site=ehost-live\%5Cnhajdu.tamas@krtk.mta.hu\%5Cnhajdu.gabor@tk.mta.hu.

Karlan, Dean, and Martin Valdivia. 2011. "Teaching Entrepreneurship: Impact of Business Training on Microfinance Clients and Institutions." Review of Economics and Statistics 93(2): 510-27. http://www.mitpressjournals.org/doi/10.1162/REST_a_00074.

Luttmer, Erzo F. P. 2005. "Neighbor as Negatives: Relative Earnings and Well-Being." The Quarterly Journal of Economics 120(3): 963-1002.

Manley, James, Seth Gitter, and Vanya Slavchevska. 2013. "How Effective Are Cash Transfers at Improving Nutritional Status?" World Development 48: 133-55. http://dx.doi.org/10.1016/j.worlddev.2013.03.010.

Mano, Yukichi, Alhassan Iddrisu, Yutaka Yoshino, and Tetsushi Sonobe. 2012. "How Can Micro and Small Enterprises in Sub-Saharan Africa Become More Productive? The Impacts of Experimental Basic Managerial Training." World Development 40(3): 458-68. http://dx.doi.org/10.1016/j.worlddev.2011.09.013.

McKenzie, David, and Christopher Woodruff. 2014. "What Are We Learning from Business Training and Entrepreneurship Evaluations around the Developing World?" World Bank Research Observer 29(1): 48-82. 
De Mel, Suresh, David McKenzie, and Christopher Woodruff. 2008. "Returns to Capital in Microenterprises: Evidence from a Field Experiment." The Quarterly Journal of Economics 123(4): 1329-72.

De Mel, Suresh, David McKenzie, and Christopher Woodruff. 2012. "One-Time Transfers of Cash or Capital Have Long-Lasting Effects on Microenterprises in Sri Lanka." Science 335(6071): 962-66.

Miller, JD. 1984. "A New Survey Technique for Studying Deviant Behavior." Phd thesis. George Washington University.

Milner, Helen V., Daniel L. Nielson, and Michael G. Findley. 2016. "Citizen Preferences and Public Goods: Comparing Preferences for Foreign Aid and Government Programs in Uganda." Review of International Organizations 11(2): 219-45. http://dx.doi.org/10.1007/s11558-016-9243-2.

Ozer, Emily J et al. 2011. “Does Alleviating Poverty Affect Mothers ' Depressive Symptoms ? A QuasiExperimental Investigation of Mexico's Oportunidades Programme." International Journal of Epidemiology (July): 1565-76.

Sundberg, Ralph, and Erik Melander, 2013, "Introducing the UCDP Georeferenced Event Dataset", Journal of Peace Research, vol.50, no.4, 523-532 
Figures and Tables

Table 1 Main outcomes of interest

\begin{tabular}{|c|c|c|}
\hline & Outcomes Name & Details \\
\hline \multicolumn{3}{|c|}{ Socio-economic outcomes - survey based } \\
\hline 1 & Employment index & $\begin{array}{l}\text { Standardized weighted average of the number of hours spend on wage } \\
\text { employed activities in the past } 7 \text { days, (log) cash wage received in the past } \\
7 \text { days, (log) outstanding wage from the past } 7 \text { days, (log) total wage in past } \\
7 \text { days, number of activities on wage employment in the past } 7 \text { days, } \\
\text { number of hours spend on self-employed activities in past } 7 \text { days, (log) self- } \\
\text { employed cash earnings in the past } 7 \text { days, (log) self-employed in-kind } \\
\text { earnings in the past } 7 \text { days, (log) outstanding earnings from the past } 7 \text { days, } \\
\text { (log) total self-employed earnings in the past } 7 \text { days, number of self- } \\
\text { employed activities in the past } 7 \text { days, total number of employees, (log) } \\
\text { business revenue during the past } 4 \text { weeks, (log) business sales yesterday, } \\
\text { (log) aggregated business costs in the past } 4 \text { weeks }\end{array}$ \\
\hline 2 & Consumption index & $\begin{array}{l}\text { Standardized weighted average of the number of different food items } \\
\text { consumed in the past } 7 \text { days, (log) total food expenditure in the past } 7 \\
\text { days, (log) value of self-produced food in the past } 7 \text { days, (log) expenditure } \\
\text { on non-food items in past } 1 \text { month, (log) expenditure on assets in past } 1 \\
\text { month }\end{array}$ \\
\hline 3 & $\begin{array}{l}\text { Savings, investment } \\
\text { and debt index }\end{array}$ & $\begin{array}{l}\text { Standardized weighted average of having or sharing a formal bank account, } \\
\text { currently saving any money, (log) amount held at bank account, (negatively } \\
\text { coded) number of formal loans received, (negatively coded) other debt, } \\
\text { (negatively coded) number of informal loans received in the past } 1 \text { month, } \\
\text { (negatively coded) (log) total amount of formal loans, (negatively coded) } \\
\text { (log) total amount of informal loans, business ownership, participation in } \\
\text { training during the past } 12 \text { months, number of trainings done in the past } 12 \\
\text { months }\end{array}$ \\
\hline 4 & Business skills index & $\begin{array}{l}\text { Standardized weighted average of frequency of visiting competitors, } \\
\text { frequency of asking customers about other products they would like to be } \\
\text { sold, frequency of setting sales targets, frequency of comparing targets to } \\
\text { performance, frequency of recording purchase and sales, knowledge of the } \\
\text { business register, knowledge of fees to register a business at cashier's } \\
\text { office of the Business Register, knowledge of operating license from State } \\
\text { government, knowledge of inspections from payam authorities, knowledge } \\
\text { of taxes, knowledge of bribes (rashua), knowledge of paying an } \\
\text { intermediate person to take care of taxes, registration of company name at } \\
\text { business register, registration at cashier's office of the Business Register, } \\
\text { obtainment of operation license from the State government, experienced } \\
\text { inspection by payam authorities, payment of formal taxes, payment of } \\
\text { bribes (rashua), payment of intermediary person to take care of taxes }\end{array}$ \\
\hline \multicolumn{3}{|c|}{ Psychological and behavioral outcomes } \\
\hline
\end{tabular}




\begin{tabular}{|c|c|c|}
\hline 5 & $\begin{array}{l}\text { Psychological } \\
\text { wellbeing index }\end{array}$ & $\begin{array}{l}\text { Standardized weighted average of happiness with education level, with } \\
\text { family, with job and work, with earnings or income, with house they live in, } \\
\text { with life as a whole, with community they live in, with security and with } \\
\text { friends, ladder of life rating self now, ladder of life rating household now, } \\
\text { ladder of life rating self in } 5 \text { years, ladder of life rating household in } 5 \text { years, } \\
\text { internal locus of control score on the possibility to become a leader based } \\
\text { on ability, on general events in life, on influencing the number of friends, } \\
\text { on control over future events, on feeling protected, on planning ahead, on } \\
\text { pleasing people above to get ahead, on (negatively coded) dependence on } \\
\text { luck to become a leader, on working hard to get ahead, on the belief that } \\
\text { own actions matter most, empowered decisions on food/clothing } \\
\text { purchases for children, on opening a business, on taking a loan, on visiting } \\
\text { a friend, on traveling to another town, on staying overnight at another } \\
\text { town, on getting a child vaccinated, on purchasing small items, on paying } \\
\text { school fees for relatives }\end{array}$ \\
\hline 6 & Risk index & $\begin{array}{l}\text { Standardized weighted average of (negatively coded) likelihood of sleeping } \\
\text { under a mosquito net, likelihood to walk alone at night, (negatively coded) } \\
\text { likelihood to spend an afternoon waiting for a medical exam, likelihood to } \\
\text { take a boda boda if the driver is unknown, likelihood to engage in } \\
\text { unprotected sex, (negatively coded) likelihood to invest in a safe business } \\
\text { accepting low profits, likelihood to invest into a business that has high profits } \\
\text { but equal chance of failing, likelihood to take a loan if there were no } \\
\text { restrictions, experimental data on number of times the more risky lottery } \\
\text { was chosen }\end{array}$ \\
\hline 7 & Trust index & $\begin{array}{l}\text { Standardized weighted average of } 13 \text { trust items: trust to people in } \\
\text { general, trust that people are helpful, (negatively coded) belief that people } \\
\text { seek their own advantage, willingness to lend money, willingness to lend } \\
\text { possessions, trust in family, trust in friends, trust in neighbors, trust in } \\
\text { police, trust in NGO, trust in elders, trust in local government, trust in state } \\
\text { government, experimental data on amount send to the WB in trust game } \\
\text { and amount send to another player in the trust game }\end{array}$ \\
\hline 8 & $\begin{array}{l}\text { Crime and violence } \\
\text { index }\end{array}$ & $\begin{array}{l}\text { Standardized weighted average of participation in a security group, } \\
\text { frequency of participation in a security group, hours participated in a } \\
\text { security group last week, experience of own cattle been stolen, number of } \\
\text { times own cattle had been stolen in the past } 1 \text { year, knowledge of a least } 1 \\
\text { home/market stall robbery, number of known home/market stall } \\
\text { robberies, experience of harassment during past } 1 \text { month, number of times } \\
\text { been harassed during past } 1 \text { month, experience of having been physically } \\
\text { punished or beaten, feeling concerned that receiving money might foster } \\
\text { crime or violence }\end{array}$ \\
\hline 10 & Migration index & $\begin{array}{l}\text { Standardized weighted average of having moved since baseline, living } \\
\text { outside SSD in the past } 1 \text { year, living in a refugee camp in the past } 1 \text { year, } \\
\text { living in an IDP camp in the past } 1 \text { year, having the wish to move }\end{array}$ \\
\hline 11 & $\begin{array}{l}\text { List experiment } \\
\text { cattle index }\end{array}$ & Standardized average of the two list experiment questions on cattle raiding \\
\hline 12 & $\begin{array}{l}\text { List experiment } \\
\text { argument index }\end{array}$ & Standardized average of the two list experiment questions on arguments \\
\hline
\end{tabular}


Table 2 Balancing original control and treatment group at baseline

\begin{tabular}{|c|c|c|c|c|c|c|c|}
\hline & & \multicolumn{2}{|c|}{ Control group } & \multicolumn{2}{|c|}{ ITT group } & \multirow{2}{*}{$\begin{array}{l}\text { Difference } \\
\text { in means }\end{array}$} & \multirow[t]{2}{*}{ p-value } \\
\hline & & $\mathrm{N}$ & Mean & $\mathrm{N}$ & Mean & & \\
\hline \multicolumn{8}{|c|}{ Individual and household characteristics } \\
\hline \multicolumn{2}{|l|}{ Age } & 1,148 & 27.417 & 1,144 & 27.683 & 0.265 & 0.2001 \\
\hline \multicolumn{2}{|l|}{ Gender } & 1,148 & 0.602 & 1,144 & 0.611 & 0.009 & 0.6559 \\
\hline \multicolumn{2}{|l|}{ Married } & 1,148 & 0.666 & 1,143 & 0.649 & -0.016 & 0.4103 \\
\hline \multicolumn{2}{|c|}{ Employment status } & 1,148 & 0.612 & 1,144 & 0.624 & 0.012 & 0.5626 \\
\hline \multicolumn{2}{|c|}{ Business ownership } & 1,148 & 0.642 & 1,144 & 0.659 & 0.017 & 0.3907 \\
\hline \multicolumn{2}{|c|}{ Consumption food } & 1,148 & 5.330 & 1,144 & 5.400 & 0.070 & 0.1740 \\
\hline \multicolumn{2}{|c|}{ Consumption nonfood } & 1,148 & 2.418 & 1,144 & 2.429 & 0.010 & 0.8547 \\
\hline \multicolumn{2}{|c|}{ Formal bank account } & 1,148 & 0.373 & 1,144 & 0.369 & -0.004 & 0.8452 \\
\hline \multirow{2}{*}{\multicolumn{2}{|c|}{$\begin{array}{l}\text { (Log) amount formal loans } \\
\text { (Log) amount informal loans }\end{array}$}} & 1,139 & -0.332 & 1,141 & -0.367 & -0.036 & 0.6339 \\
\hline & & 1,134 & -1.329 & 1,124 & -1.225 & 0.104 & 0.4432 \\
\hline \multirow{5}{*}{$\begin{array}{l}\text { Education } \\
\text { level }\end{array}$} & No education & 1,148 & 0.191 & 1,144 & 0.206 & 0.016 & 0.3517 \\
\hline & Some Primary & 1,148 & 0.315 & 1,144 & 0.330 & 0.015 & 0.4401 \\
\hline & Some & 1,148 & 0.404 & 1,144 & 0.373 & -0.031 & 0.1289 \\
\hline & Secondary & & & & & & \\
\hline & $\begin{array}{l}\text { Some University } \\
\text { or Higher }\end{array}$ & 1,148 & 0.090 & 1,144 & 0.090 & 0.000 & 0.9791 \\
\hline \multirow[t]{3}{*}{ Literacy } & No English & 1,148 & 0.247 & 1,144 & 0.263 & 0.016 & 0.3882 \\
\hline & Some English & 1,148 & 0.273 & 1,144 & 0.295 & 0.022 & 0.2443 \\
\hline & Good English & 1,148 & 0.480 & 1,144 & 0.442 & $-0.038 *$ & 0.0706 \\
\hline \multirow[t]{3}{*}{ Numeracy } & Low & 1,148 & 0.238 & 1,144 & 0.247 & 0.010 & 0.5931 \\
\hline & Medium & 1,148 & 0.160 & 1,144 & 0.198 & $0.037 * *$ & 0.0199 \\
\hline & High & 1,148 & 0.602 & 1,144 & 0.555 & $-0.047^{* *}$ & 0.0231 \\
\hline \multicolumn{2}{|c|}{ Household size } & 1,148 & 7.310 & 1,144 & 7.260 & -0.050 & 0.7257 \\
\hline \multicolumn{2}{|c|}{ Number of children } & 1,148 & 3.107 & 1,144 & 3.241 & 0.134 & 0.1635 \\
\hline \multicolumn{2}{|c|}{ Number of elderly } & 1,148 & 0.109 & 1,144 & 0.087 & -0.021 & 0.1292 \\
\hline \multicolumn{2}{|c|}{ Number of rooms } & 1,148 & 3.180 & 1,144 & 3.087 & -0.093 & 0.1935 \\
\hline \multicolumn{2}{|c|}{ Number of buildings } & 1,148 & 3.676 & 1,144 & 3.538 & $-0.138 *$ & 0.0830 \\
\hline \multicolumn{2}{|c|}{ (Log) distance to KCB branch } & 1,130 & 2.395 & 1,126 & 2.396 & 0.001 & 0.9871 \\
\hline \multicolumn{2}{|c|}{$\begin{array}{l}\text { Conflict exposure 2011-2014 } \\
\text { (300km buffer) }\end{array}$} & 1,148 & 0.000 & 1,144 & 0.084 & 0.084 & 0.3283 \\
\hline \multicolumn{2}{|c|}{$\begin{array}{l}\text { Conflict exposure 2015-2017 } \\
\text { (300km buffer) }\end{array}$} & 1,148 & 0.000 & 1,144 & 0.128 & $0.128^{*}$ & 0.0953 \\
\hline \multicolumn{8}{|c|}{ State at baseline } \\
\hline Central Equ & toria & 1,148 & 0.169 & 1,144 & 0.167 & -0.002 & 0.8966 \\
\hline Eastern Equ & toria & 1,148 & 0.160 & 1,144 & 0.152 & -0.008 & 0.5898 \\
\hline Lakes & & 1,148 & 0.158 & 1,144 & 0.159 & 0.001 & 0.9256 \\
\hline Northern B & or El Ghazal & 1,148 & 0.170 & 1,144 & 0.176 & 0.006 & 0.7118 \\
\hline Western $\mathrm{B}$ & r El Ghazal & 1,148 & 0.172 & 1,144 & 0.171 & -0.000 & 0.9861 \\
\hline Western Ec & atoria & 1,148 & 0.172 & 1,144 & 0.175 & 0.003 & 0.8386 \\
\hline
\end{tabular}

Note: All indicators were measured at baseline. ${ }^{*}(* *, * *)$ indicates statistical significance at the ten-percent (five-percent, one-percent) level. 


\begin{tabular}{|c|c|c|c|c|c|c|}
\hline & & \multicolumn{2}{|c|}{ „training, no grant" } & \multicolumn{2}{|c|}{ „training and grant" } & \multirow[t]{2}{*}{$\mathrm{N}$} \\
\hline & & Mean & SD & Coeff. & SE & \\
\hline \multicolumn{7}{|c|}{ Individual and household characteristics } \\
\hline \multicolumn{2}{|l|}{ Age } & 27.570 & 4.691 & $5.594 * * *$ & 1.280 & 626 \\
\hline \multicolumn{2}{|l|}{ Married } & 0.606 & 0.489 & $0.160 * * *$ & 0.053 & 626 \\
\hline \multicolumn{2}{|c|}{ Employment status } & 0.656 & 0.476 & $0.134 * *$ & 0.058 & 626 \\
\hline \multicolumn{2}{|c|}{ Business ownership } & 0.642 & 0.480 & $0.215 * * *$ & 0.049 & 626 \\
\hline \multicolumn{2}{|c|}{ Consumption food } & 5.390 & 1.150 & $0.908 * * *$ & 0.216 & 626 \\
\hline \multicolumn{2}{|c|}{ Consumption nonfood } & 2.398 & 1.322 & $0.676 * * *$ & 0.137 & 626 \\
\hline \multicolumn{2}{|c|}{ Formal bank account } & 0.421 & 0.494 & $0.137^{* * *}$ & 0.047 & 626 \\
\hline \multirow{2}{*}{\multicolumn{2}{|c|}{$\begin{array}{l}\text { (Log) amount formal loans } \\
\text { (Log) amount informal loans }\end{array}$}} & -0.338 & 1.756 & -0.140 & 0.171 & 625 \\
\hline & & -0.972 & 2.892 & $-0.522 *$ & 0.267 & 614 \\
\hline \multirow{5}{*}{$\begin{array}{l}\text { Education } \\
\text { level }\end{array}$} & No education & 0.173 & 0.379 & -0.056 & 0.044 & 626 \\
\hline & Some Primary & 0.308 & 0.462 & $0.078^{*}$ & 0.044 & 626 \\
\hline & Some & 0.399 & 0.490 & $0.164 * * *$ & 0.046 & 626 \\
\hline & Secondary & & & & & \\
\hline & $\begin{array}{l}\text { Some University } \\
\text { or Higher }\end{array}$ & 0.120 & 0.326 & -0.002 & 0.029 & 626 \\
\hline \multirow[t]{3}{*}{ Literacy } & No English & 0.233 & 0.423 & $-0.080^{*}$ & 0.042 & 626 \\
\hline & Some English & 0.269 & 0.444 & $0.131 * * *$ & 0.041 & 626 \\
\hline & Good English & 0.498 & 0.501 & $0.133^{* *}$ & 0.056 & 626 \\
\hline \multirow[t]{3}{*}{ Numeracy } & Low & 0.192 & 0.395 & -0.022 & 0.036 & 626 \\
\hline & Medium & 0.216 & 0.412 & -0.006 & 0.040 & 626 \\
\hline & High & 0.591 & 0.492 & $0.212 * * *$ & 0.058 & 626 \\
\hline \multicolumn{2}{|c|}{ Household size } & 7.058 & 3.215 & $1.648 * * *$ & 0.508 & 626 \\
\hline \multicolumn{2}{|c|}{ Number of children } & 3.171 & 2.239 & $0.628 * *$ & 0.284 & 626 \\
\hline \multicolumn{2}{|c|}{ Number of elderly } & 0.072 & 0.332 & 0.039 & 0.036 & 626 \\
\hline \multicolumn{2}{|c|}{ Number of rooms } & 3.240 & 1.698 & $0.533 * * *$ & 0.191 & 626 \\
\hline \multicolumn{2}{|c|}{ Number of buildings } & 3.639 & 2.029 & $0.783 * * *$ & 0.293 & 626 \\
\hline \multicolumn{2}{|c|}{ (Log) distance to KCB branch } & 2.749 & 2.089 & 0.078 & 0.170 & 617 \\
\hline \multicolumn{2}{|c|}{$\begin{array}{l}\text { Conflict exposure 2011-2014 } \\
\text { (300km buffer) }\end{array}$} & 0.208 & 4.393 & -0.149 & 0.166 & 626 \\
\hline \multicolumn{2}{|c|}{$\begin{array}{l}\text { Conflict exposure 2015-2017 } \\
\text { (300km buffer) }\end{array}$} & 0.136 & 3.728 & -0.195 & 0.157 & 626 \\
\hline \multicolumn{7}{|c|}{ State at baseline } \\
\hline \multicolumn{2}{|c|}{ Central Equatoria } & 0.188 & 0.391 & $0.019 * *$ & 0.009 & 626 \\
\hline \multicolumn{2}{|c|}{ Eastern Equatoria } & 0.240 & 0.428 & $0.000 * * *$ & 0.000 & 626 \\
\hline \multicolumn{2}{|l|}{ Lakes } & 0.063 & 0.242 & $0.000 * * *$ & 0.000 & 626 \\
\hline Northern B & ir El Ghazal & 0.125 & 0.331 & $0.178 * * *$ & 0.043 & 626 \\
\hline Western Ba & r El Ghazal & 0.091 & 0.288 & -0.004 & 0.004 & 626 \\
\hline Western Eq & atoria & 0.293 & 0.456 & $-0.009 *$ & 0.006 & 626 \\
\hline
\end{tabular}

Note: Differences between treatment group participants that received that grant and those who did not use baseline characteristics. Column (1) reports mean values of baseline covariates for participants that received training but no grant". Column (2) reports OLS estimates on receiving "training and grant" and strata fixed effect. Standard errors are clustered at boma level and reported below coefficients in parenthesis. ${ }^{*}\left({ }^{* *},{ }^{* * *}\right)$ indicates statistical significance at the ten-percent (fivepercent, one-percent) level." 
Table 4 Summary statistics of outcome variables for the control group

\begin{tabular}{lccccc}
\hline VARIABLES & $\mathrm{N}$ & mean & sd & min & max \\
\hline & Main outcomes & (survey-based) & & & \\
\hline Employment index & 763 & 0 & 1 & -2.314 & 6.401 \\
Consumption index & 763 & 0 & 1 & -1.580 & 5.037 \\
Savings, investment and debt index & 763 & 0 & 1 & -4.013 & 2.984 \\
Business skills index & 763 & 0 & 1 & -2.971 & 2.569 \\
Psychological wellbeing index & 763 & 0 & 1 & -2.625 & 3.606 \\
Risk index & 763 & 0 & 1 & -2.789 & 3.142 \\
Trust index & 763 & 0 & 1 & -2.982 & 3.147 \\
Crime and violence index & 763 & 0 & 1 & -1.214 & 5.667 \\
Migration index & 763 & 0 & 1 & -0.838 & 3.740 \\
List experiment cattle index & 763 & 0 & 1 & -3.360 & 3.095 \\
List experiment argument index & 763 & 0 & 1 & -3.666 & 4.163 \\
\hline
\end{tabular}

Note: Higher values of all indicators refer to higher scores in the respective outcome. For instance, higher values in the risk index imply a higher preference for risky behavior. Higher values in the list experiment cattle index imply a higher propensity to engage in cattle raiding, while higher values in the list experiment argument index imply a higher propensity to engage in arguments. Higher values of the migration index mark a higher propensity of having, or planning to migrate. 


\begin{tabular}{lcc} 
Table 5 Intention-to-treat effects of the original intervention on main socio-economic outcomes & $(1)$ & $(2)$ \\
& ITT & ITT \\
& (no controls) & (controls) \\
\hline \multicolumn{3}{c}{ Main outcomes - Socioeconomic } \\
\hline Employment index & 0.063 & 0.067 \\
& $(0.281)$ & $(0.242)$ \\
Consumption index & {$[0.375]$} & {$[0.323]$} \\
& 0.094 & 0.086 \\
Savings, investment and debt & $(0.120)$ & $(0.153)$ \\
index & {$[0.240]$} & {$[0.307]$} \\
& $0.274^{* * *}$ & $0.271 * * *$ \\
Business skills index & $(0.000)$ & $(0.000)$ \\
& {$[0.001]$} & {$[0.001]$} \\
& 0.016 & 0.018 \\
& $(0.747)$ & $(0.735)$ \\
\hline Observations & {$[0.748]$} & {$[0.735]$} \\
\hline
\end{tabular}

Note: P-values are in parenthesis displayed below the estimated coefficients. ${ }^{*}(* *, * * *)$ indicates statistical significance at the ten-percent (five-percent, one-percent) level. Adjusted Benjamini-Hochberg p-values are reported in square brackets. All regression control for gender-state fixed effects. Control variables of column (2) include all baseline controls that were significant determinants of attrition and of selection between receiving "training and grant" vs "training, but no grant". In particular, these are age, marital status, employment status, business ownership, food consumption, non-food consumption, formal bank account, formal loans, informal loans, education level, literacy level, numeracy level, household size, number of children, number of rooms, number of buildings at baseline, and exposure to conflict events between baseline and endline. 
Table 6 Intention-to-treat effects of the original intervention on main psychological and behavioral outcomes

\begin{tabular}{lcc} 
& $\begin{array}{c}(1) \\
\text { ITT } \\
\text { Main outcomes }- \text { Psychological and behavioral }\end{array}$ & $\begin{array}{c}(2) \\
\text { ITT } \\
\text { (controls) }\end{array}$ \\
\hline & -0.009 & 0.002 \\
Psychological wellbeing index & $(0.845)$ & $(0.965)$ \\
Risk index & {$[0.845]$} & {$[0.965]$} \\
& -0.043 & -0.052 \\
Trust index & $(0.501)$ & $(0.383)$ \\
& {$[0.692]$} & {$[0.537]$} \\
Crime and violence index & -0.035 & -0.055 \\
& $(0.482)$ & $(0.274)$ \\
Migration index & {$[0.692]$} & {$[0.480]$} \\
& -0.080 & $-0.089 *$ \\
List experiment cattle index & $(0.119)$ & $(0.090)$ \\
& {$[0.343]$} & {$[0.315]$} \\
List experiment argument index & -0.026 & -0.015 \\
& $(0.593)$ & $(0.767)$ \\
\hline Observations & {$[0.692]$} & {$[0.896]$} \\
& $0.172 *$ & $0.169 * *$ \\
& $(0.075)$ & $(0.050)$ \\
& {$[0.343]$} & {$[0.315]$} \\
& -0.135 & -0.132 \\
& $(0.147)$ & $(0.149)$ \\
& {$[0.343]$} & {$[0.322]$} \\
\hline
\end{tabular}

Note: P-values are in parenthesis displayed below the estimated coefficients. ${ }^{*}\left({ }^{*},{ }^{* * *}\right)$ indicates statistical significance at the ten-percent (five-percent, one-percent) level. Adjusted Benjamini-Hochberg p-values are reported in square brackets. All regression control for gender-state fixed effects. Control variables of column (2) include all baseline controls that were significant determinants of attrition and of selection between receiving "training and grant" vs "training, but no grant". In particular, these are age, marital status, employment status, business ownership, food consumption, non-food consumption, formal bank account, formal loans, informal loans, education level, literacy level, numeracy level, household size, number of children, number of rooms, number of buildings at baseline, and exposure to conflict between baseline and endline. 
Table 7 First stage results from LATE estimation of Table 8 and Table 9

(1)

(2)

(3)

(4)

(5)

(6)

\begin{tabular}{|c|c|c|c|c|c|c|c|}
\hline & & "Training, no grant" & "Training and grant" & „Training, no grant" & "Training and grant" & „Training, no grant" & "Training and grant" \\
\hline \multirow[t]{2}{*}{ Instrument 1} & Treatment & $0.4226^{* * *}$ & $0.3860 * * *$ & $0.4196 * * *$ & $0.3875^{* * *}$ & $0.4414 * * *$ & $0.4254 * * *$ \\
\hline & & $(0.000)$ & $(0.000)$ & $(0.000)$ & $(0.000)$ & $(0.002)$ & $(0.000)$ \\
\hline \multirow[t]{8}{*}{ Instrument 2} & $\begin{array}{l}\text { Treatment } \mathrm{x} \\
(\log )\end{array}$ & $0.0517^{* * *}$ & $-0.0450 * * *$ & $0.0523^{* * *}$ & $-0.0442 * * *$ & $0.0716^{* * *}$ & $-0.0620 * * *$ \\
\hline & $\begin{array}{l}\text { distance to } \\
\mathrm{KCB} \text { branch }\end{array}$ & $(0.002)$ & (0.001) & $(0.003)$ & (0.001) & $(0.000)$ & $(0.000)$ \\
\hline & $(\log )$ & -0.0032 & 0.0050 & -0.0050 & 0.0081 & -0.0093 & 0.0143 \\
\hline & $\begin{array}{l}\text { Distance to } \\
\text { KCB branch }\end{array}$ & $(0.661)$ & $(0.454)$ & (0.549) & $(0.261)$ & $(0.418)$ & (0.107) \\
\hline & Strata FE & Yes & Yes & Yes & Yes & Yes & Yes \\
\hline & $\begin{array}{l}\text { Individual } \\
\text { controls }\end{array}$ & No & No & Yes & Yes & Yes & Yes \\
\hline & $\begin{array}{l}\text { Geography } \\
\text { controls }\end{array}$ & No & No & No & No & Yes & Yes \\
\hline & Observations & 1,500 & 1,500 & 1,474 & 1,474 & 1,474 & 1,474 \\
\hline
\end{tabular}

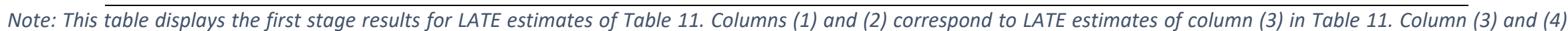

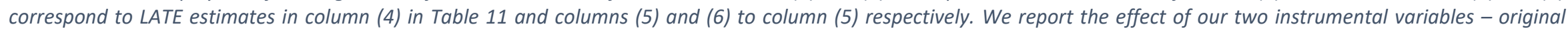
assignment to the treatment group and its interaction with distance to the closest KCB bank branch - on our two main regressors of interest. All regression control for genderstate fixed effects and for the level effect of distance to the closest KCB bank branch. Control variables of column (3)-(6) include all baseline controls that were significant

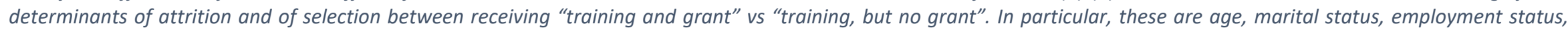
business ownership, food consumption, non-food consumption, formal bank account, formal loans, informal loans, education level, literacy level, numeracy level, household size,

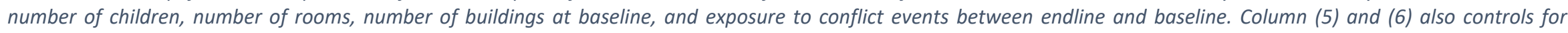
geographic features since the estimation strategy relies on the distance to the closest KCB bank branch, which might correlate with other geographic characteristics. Geography

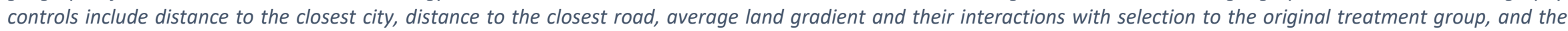

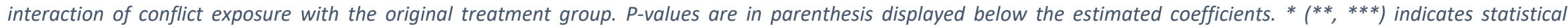
significance at the ten-percent (five-percent, one-percent) level 
Table 8 Effects of the "training and grant" vs "training, but no grant" on main socio-economic outcomes

\begin{tabular}{|c|c|c|c|c|c|c|c|}
\hline & & (1) & $(2)$ & (3) & (4) & (5) & (6) \\
\hline & & $\begin{array}{c}\text { TOT } \\
\text { (no } \\
\text { controls) }\end{array}$ & $\begin{array}{c}\text { TOT } \\
\text { (controls) }\end{array}$ & $\begin{array}{c}\text { TOT } \\
\text { (controls } \\
+ \\
\text { geography } \\
\text { controls) }\end{array}$ & $\begin{array}{c}\text { LATE } \\
\text { (no } \\
\text { controls) }\end{array}$ & $\begin{array}{c}\text { LATE } \\
\text { (controls) }\end{array}$ & $\begin{array}{c}\text { LATE } \\
\text { (controls } \\
+ \\
\text { geography } \\
\text { controls) }\end{array}$ \\
\hline \multicolumn{8}{|c|}{ Main outcomes - Socio-economic } \\
\hline \multirow{6}{*}{$\begin{array}{l}\text { Employment } \\
\text { index }\end{array}$} & Training, & 0.087 & 0.086 & 0.081 & -0.069 & -0.050 & 0.064 \\
\hline & no grant & $(0.149)$ & $(0.134)$ & $(0.424)$ & $(0.766)$ & $(0.818)$ & $(0.833)$ \\
\hline & & {$[0.238]$} & {$[0.215]$} & [0.679] & [0.968] & [0.988] & [0.989] \\
\hline & Training & 0.057 & 0.062 & 0.044 & 0.369 & 0.338 & 0.082 \\
\hline & and grant & $(0.580)$ & $(0.554)$ & $(0.752)$ & $(0.384)$ & $(0.391)$ & $(0.820)$ \\
\hline & & {$[0.595]$} & {$[0.676]$} & [0.813] & [0.655] & {$[0.626]$} & [0.989] \\
\hline \multirow{6}{*}{$\begin{array}{l}\text { Consumption } \\
\text { index }\end{array}$} & Training, & 0.046 & 0.037 & 0.026 & $-0.389 * *$ & $-0.350 * *$ & -0.136 \\
\hline & no grant & $(0.489)$ & $(0.591)$ & $(0.810)$ & (0.019) & $(0.029)$ & (0.659) \\
\hline & & [0.595] & [0.676] & [0.813] & [0.071] & [0.077] & [0.989] \\
\hline & Training & $0.178 * *$ & $0.157^{* *}$ & 0.169 & $1.042 * *$ & $0.933 * *$ & $1.049 * *$ \\
\hline & and grant & $(0.023)$ & $(0.048)$ & $(0.166)$ & $(0.027)$ & $(0.027)$ & $(0.015)$ \\
\hline & & {$[0.046]$} & [0.096] & [0.332] & [0.071] & [0.077] & {$[0.060]$} \\
\hline \multirow{6}{*}{$\begin{array}{l}\text { Savings, } \\
\text { investment } \\
\text { and debt } \\
\text { index }\end{array}$} & Training, & $0.221 * * *$ & $0.205^{* * *}$ & 0.127 & -0.166 & -0.171 & -0.200 \\
\hline & no grant & $(0.000)$ & $(0.000)$ & $(0.147)$ & $(0.275)$ & $(0.278)$ & $(0.483)$ \\
\hline & & [0.001] & [0.001] & [0.332] & [0.572] & [0.556] & [0.989] \\
\hline & Training & $0.434 * * *$ & $0.420 * * *$ & $0.327 * * *$ & $1.282 * * *$ & $1.270 * * *$ & $0.992 * * *$ \\
\hline & and grant & $(0.000)$ & $(0.000)$ & $(0.001)$ & $(0.001)$ & $(0.001)$ & $(0.007)$ \\
\hline & & {$[0.001]$} & {$[0.001]$} & [0.008] & [0.006] & [0.005] & [0.054] \\
\hline \multirow{6}{*}{$\begin{array}{l}\text { Business } \\
\text { skills index }\end{array}$} & Training, & -0.031 & -0.022 & 0.024 & -0.113 & 0.003 & 0.024 \\
\hline & no grant & $(0.594)$ & $(0.727)$ & $(0.813)$ & $(0.520)$ & (0.988) & (0.929) \\
\hline & & [0.595] & [0.728] & [0.813] & [0.974] & [0.988] & [0.989] \\
\hline & Training & $0.240 * * *$ & $0.220 * * *$ & $0.299 * *$ & 0.267 & 0.046 & -0.005 \\
\hline & and grant & $(0.004)$ & $(0.010)$ & $(0.017)$ & $(0.442)$ & $(0.903)$ & (0.988) \\
\hline & & {$[0.012]$} & {$[0.027]$} & [0.069] & [0.968] & [0.988] & [0.989] \\
\hline Observations & & 1,523 & 1,495 & 1,474 & 1,500 & 1,474 & 1,474 \\
\hline F-stat & & & & & 23.88 & 21.61 & 36.61 \\
\hline
\end{tabular}

Note: P-values are in parenthesis displayed below the estimated coefficients. * (**, ***) indicates statistical significance at the ten-percent (five-percent, one-percent) level. Adjusted Benjamini-Hochberg p-values are reported in square brackets. All regression control for gender-state fixed effects. Control variables of column (2) include all baseline controls that were significant determinants of attrition and of selection between receiving "training and grant" vs "training, but no grant". In particular, these are age, marital status, employment status, business ownership, food consumption, non-food consumption, formal bank account, formal loans, informal loans, education level, literacy level, numeracy level, household size, number of children, number of rooms, number of buildings at baseline, and exposure to conflict events between baseline and endline. Column (3) also controls for geographic features since the estimation strategy relies on distance to the closest KCB bank branch which might correlate with other geographic characteristics. Geography controls include distance to the closest city, distance to the closest road, average land gradient and their respective interactions with selection to the original treatment group. 
Table 9 Effects of the "training and grant" vs "training, but no grant" on main psychological and behavioral outcomes

\begin{tabular}{|c|c|c|c|c|c|c|c|}
\hline & & $\begin{array}{c}\text { (1) } \\
\text { TOT } \\
\text { (no } \\
\text { controls) }\end{array}$ & $\begin{array}{c}(2) \\
\text { TOT } \\
\text { (controls) }\end{array}$ & $\begin{array}{c}\text { (3) } \\
\text { TOT } \\
\text { (controls } \\
+ \\
\text { geography } \\
\text { controls) }\end{array}$ & $\begin{array}{c}\text { (4) } \\
\text { LATE } \\
\text { (no } \\
\text { controls) }\end{array}$ & $\begin{array}{c}\text { (5) } \\
\text { LATE } \\
\text { (controls) }\end{array}$ & $\begin{array}{c}\text { (5) } \\
\text { LATE } \\
\text { (controls } \\
+ \\
\text { geography } \\
\text { controls) }\end{array}$ \\
\hline \multicolumn{8}{|c|}{ Main outcomes - Psychological and behavioral } \\
\hline \multirow{6}{*}{$\begin{array}{l}\text { Psychological } \\
\text { wellbeingindex }\end{array}$} & Training, no & 0.029 & 0.035 & 0.127 & -0.238 & -0.080 & 0.196 \\
\hline & grant & $(0.585)$ & $(0.490)$ & $(0.139)$ & $(0.151)$ & $(0.614)$ & $(0.373)$ \\
\hline & & {$[0.745]$} & [0.624] & [0.324] & [0.389] & [0.749] & [0.746] \\
\hline & Training and & 0.027 & -0.014 & 0.064 & 0.397 & 0.131 & $0.701 * *$ \\
\hline & grant & $(0.716)$ & $(0.847)$ & $(0.505)$ & $(0.229)$ & $(0.672)$ & $(0.027)$ \\
\hline & & {$[0.795]$} & [0.913] & {$[0.708]$} & [0.389] & [0.749] & [0.372] \\
\hline \multirow[t]{6}{*}{ Risk index } & Training, no & 0.016 & 0.000 & 0.106 & -0.441 & -0.408 & -0.109 \\
\hline & grant & $(0.839)$ & (0.998) & $(0.322)$ & (0.103) & $(0.104)$ & $(0.794)$ \\
\hline & & {$[0.840]$} & [0.998] & [0.574] & [0.389] & [0.369] & [0.955] \\
\hline & Training and & -0.068 & -0.076 & 0.028 & 0.702 & 0.605 & 0.712 \\
\hline & grant & $(0.365)$ & $(0.327)$ & $(0.780)$ & $(0.194)$ & $(0.231)$ & $(0.106)$ \\
\hline & & [0.640] & [0.464] & [0.840] & [0.389] & [0.462] & [0.372] \\
\hline \multirow[t]{6}{*}{ Trust index } & Training, no & -0.077 & -0.096 & -0.038 & -0.020 & -0.020 & $-0.501 *$ \\
\hline & grant & $(0.182)$ & $(0.105)$ & $(0.740)$ & $(0.920)$ & $(0.923)$ & $(0.064)$ \\
\hline & & {$[0.365]$} & [0.378] & [0.840] & [0.921] & [0.924] & [0.372] \\
\hline & Training and & 0.128 & 0.131 & $0.211^{*}$ & -0.098 & -0.153 & -0.021 \\
\hline & grant & $(0.122)$ & $(0.111)$ & (0.095) & $(0.792)$ & (0.695) & $(0.955)$ \\
\hline & & {$[0.365]$} & [0.378] & [0.324] & [0.853] & [0.749] & [0.955] \\
\hline \multirow{6}{*}{$\begin{array}{l}\text { Crime and } \\
\text { violence index }\end{array}$} & Training, no & -0.051 & -0.061 & 0.010 & $-0.470 *$ & $-0.554^{*}$ & -0.277 \\
\hline & grant & $(0.414)$ & $(0.331)$ & (0.905) & $(0.100)$ & $(0.062)$ & $(0.361)$ \\
\hline & & [0.645] & [0.464] & [0.906] & [0.389] & [0.369] & {$[0.746]$} \\
\hline & Training and & -0.104 & -0.103 & -0.089 & 0.578 & 0.692 & 0.155 \\
\hline & grant & $(0.170)$ & $(0.190)$ & $(0.356)$ & $(0.250)$ & $(0.185)$ & $(0.669)$ \\
\hline & & {$[0.365]$} & [0.378] & [0.574] & [0.389] & [0.432] & [0.937] \\
\hline \multirow{6}{*}{$\begin{array}{l}\text { Migration } \\
\text { index }\end{array}$} & Training, no & -0.080 & -0.078 & $-0.148^{*}$ & -0.258 & -0.292 & -0.307 \\
\hline & grant & $(0.150)$ & $(0.167)$ & $(0.098)$ & (0.119) & (0.105) & $(0.251)$ \\
\hline & & {$[0.365]$} & [0.378] & [0.324] & [0.389] & [0.369] & [0.703] \\
\hline & Training and & 0.029 & 0.018 & -0.053 & 0.449 & 0.543 & -0.043 \\
\hline & grant & $(0.738)$ & $(0.823)$ & $(0.594)$ & $(0.223)$ & $(0.157)$ & $(0.890)$ \\
\hline & & [0.795] & [0.913] & {$[0.757]$} & [0.389] & [0.432] & [0.955] \\
\hline \multirow{6}{*}{$\begin{array}{l}\text { List } \\
\text { experiment } \\
\text { cattle index }\end{array}$} & Training, no & $0.207^{*}$ & $0.222 * *$ & $0.250 * *$ & 0.108 & 0.112 & 0.166 \\
\hline & grant & $(0.052)$ & $(0.040)$ & $(0.026)$ & $(0.666)$ & $(0.688)$ & $(0.558)$ \\
\hline & & {$[0.365]$} & {$[0.378]$} & [0.324] & {$[0.777]$} & [0.749] & [0.904] \\
\hline & Training and & -0.089 & -0.103 & -0.080 & 0.410 & 0.392 & 0.336 \\
\hline & grant & $(0.565)$ & $(0.216)$ & $(0.369)$ & $(0.457)$ & (0.519) & $(0.581)$ \\
\hline & & {$[0.745]$} & [0.378] & [0.574] & {$[0.582]$} & [0.749] & [0.904] \\
\hline \multirow{6}{*}{$\begin{array}{l}\text { List } \\
\text { experiment } \\
\text { argument } \\
\text { index }\end{array}$} & Training, no & -0.157 & -0.130 & $-0.176^{*}$ & $-0.431^{*}$ & $-0.352 *$ & $-0.334 *$ \\
\hline & grant & $(0.112)$ & (0.191) & $(0.082)$ & $(0.060)$ & $(0.084)$ & $(0.089)$ \\
\hline & & {$[0.365]$} & [0.378] & [0.324] & [0.389] & [0.369] & {$[0.372]$} \\
\hline & Training and & -0.224 & -0.256 & -0.245 & 0.400 & 0.217 & 0.099 \\
\hline & grant & $(0.148)$ & $(0.121)$ & $(0.130)$ & $(0.432)$ & $(0.662)$ & $(0.838)$ \\
\hline & & [0.365] & [0.378] & [0.324] & [0-582] & [0.749] & [0.955] \\
\hline Observations & & 1,523 & 1,495 & 1,474 & 1,500 & 1,474 & 1,474 \\
\hline F-stat & & & & & 23.88 & 21.61 & 36.61 \\
\hline
\end{tabular}

Note: P-values are in parenthesis displayed below the estimated coefficients. * $(* *, * * *)$ indicates statistical significance at the ten-percent (five-percent, one-percent) level. Adjusted Benjamini-Hochberg p-values are reported in square brackets. All regression control for gender-state fixed effects. Control variables of column (2) include all baseline controls that were significant determinants of attrition and of selection between receiving "training and grant" vs "training, but no grant". In particular, these are age, marital status, employment status, 
business ownership, food consumption, non-food consumption, formal bank account, formal loans, informal loans, education level, literacy level, numeracy level, household size, number of children, number of rooms, number of buildings at baseline, and exposure to conflict events between baseline and endline. Column (3) also controls for geographic features since the estimation strategy relies on the distance to the closest KCB bank branch that might correlate with other geographic characteristics. Geography controls include distance to the closest city, distance to the closest road, average land gradient and their respective interactions with selection to the original treatment group. 


\section{Appendix 1 - Additional Balance Tables}

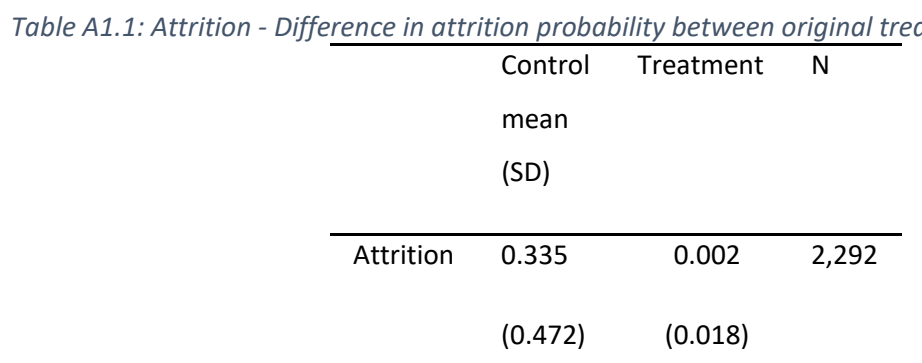

Note: Difference in attrition probability between original treatment vs. control group, estimated with an OLS regression of the attrition dummy on the treatment dummy and strata fixed effects. The standard error of the treatment dummy is clustered at boma level and reported in parentheses. ${ }^{*}(*, * * *)$ indicates statistical significance at the ten-percent (five-percent, onepercent) level. 
Table A1.2: Attrition - Baseline difference between attritors and non-attritors

\begin{tabular}{|c|c|c|c|c|c|c|}
\hline & & \multicolumn{2}{|c|}{ Non-attritors } & \multicolumn{2}{|c|}{ Attritors } & \multirow[t]{2}{*}{$\mathrm{N}$} \\
\hline & & Mean & SD & Coeff. & SE & \\
\hline \multicolumn{7}{|c|}{ Individual and household characteristics } \\
\hline \multicolumn{2}{|l|}{ Age } & 27.632 & 4.826 & -0.281 & 0.236 & 2,292 \\
\hline \multicolumn{2}{|l|}{ Married } & 0.661 & 0.473 & -0.025 & 0.026 & 2,291 \\
\hline \multicolumn{2}{|c|}{ Employment status } & 0.619 & 0.486 & 0.004 & 0.020 & 2,292 \\
\hline \multicolumn{2}{|c|}{ Business ownership } & 0.649 & 0.478 & 0.011 & 0.018 & 2,292 \\
\hline \multicolumn{2}{|c|}{ Consumption food } & 5.405 & 1.170 & $-0.108 * *$ & 0.051 & 2,292 \\
\hline \multicolumn{2}{|c|}{ Consumption nonfood } & 2.432 & 1.325 & 0.004 & 0.063 & 2,292 \\
\hline \multicolumn{2}{|c|}{ Formal bank account } & 0.397 & 0.489 & $-0.068 * * *$ & 0.021 & 2,292 \\
\hline \multicolumn{2}{|c|}{ (Log) amount formal loans } & -0.290 & 1.626 & $-0.183^{* *}$ & 0.088 & 2,280 \\
\hline \multicolumn{2}{|c|}{ (Log) amount informal loans } & -1.360 & 3.323 & $0.275^{* *}$ & 0.132 & 2,258 \\
\hline Education & No education & 0.210 & 0.408 & $-0.035^{*}$ & 0.019 & 2,292 \\
\hline \multirow[t]{4}{*}{ level } & Some Primary & 0.307 & 0.462 & $0.059 * * *$ & 0.019 & 2,292 \\
\hline & Some & 0.379 & 0.485 & 0.019 & 0.022 & 2,292 \\
\hline & Secondary & & & & & \\
\hline & $\begin{array}{l}\text { Some University } \\
\text { or Higher }\end{array}$ & 0.104 & 0.305 & $-0.042 * * *$ & 0.011 & 2,292 \\
\hline \multirow[t]{3}{*}{ Literacy } & No English & 0.261 & 0.440 & -0.012 & 0.020 & 2,292 \\
\hline & Some English & 0.286 & 0.452 & 0.003 & 0.020 & 2,292 \\
\hline & Good English & 0.453 & 0.498 & 0.009 & 0.023 & 2,292 \\
\hline \multirow[t]{3}{*}{ Numeracy } & Low & 0.252 & 0.434 & -0.026 & 0.018 & 2,292 \\
\hline & Medium & 0.173 & 0.378 & 0.028 & 0.017 & 2,292 \\
\hline & High & 0.575 & 0.494 & -0.002 & 0.020 & 2,292 \\
\hline \multicolumn{2}{|c|}{ Household size } & 7.384 & 3.342 & $-0.299 * *$ & 0.144 & 2,292 \\
\hline \multicolumn{2}{|c|}{ Number of children } & 3.248 & 2.294 & $-0.211^{* *}$ & 0.104 & 2,292 \\
\hline \multicolumn{2}{|c|}{ Number of elderly } & 0.098 & 0.344 & -0.002 & 0.014 & 2,292 \\
\hline \multicolumn{2}{|c|}{ Number of rooms } & 3.179 & 1.691 & -0.125 & 0.078 & 2,292 \\
\hline \multicolumn{2}{|c|}{ Number of buildings } & 3.611 & 1.989 & -0.016 & 0.077 & 2,292 \\
\hline \multicolumn{2}{|c|}{ (Log) distance to KCB branch } & 2.338 & 1.938 & $0.227^{*}$ & 0.132 & 2,256 \\
\hline \multicolumn{2}{|c|}{$\begin{array}{l}\text { Conflict exposure 2011-14 } \\
\text { (300km buffer) }\end{array}$} & 0.074 & 2.427 & $-0.083^{*}$ & 0.049 & 2,292 \\
\hline \multicolumn{2}{|c|}{$\begin{array}{l}\text { Conflict exposure } 2015-2017 \\
\text { (300km buffer) }\end{array}$} & 0.083 & 2.139 & -0.056 & 0.057 & 2,292 \\
\hline \multicolumn{7}{|c|}{ State at baseline } \\
\hline \multicolumn{2}{|c|}{ Central Equatoria } & 0.171 & 0.376 & 0.008 & 0.007 & 2,292 \\
\hline \multicolumn{2}{|c|}{ Eastern Equatoria } & 0.154 & 0.361 & -0.001 & 0.001 & 2,292 \\
\hline Lakes & & 0.147 & 0.354 & 0.001 & 0.001 & 2,292 \\
\hline Northern B & ir El Ghazal & 0.175 & 0.380 & -0.005 & 0.004 & 2,292 \\
\hline Western B & El Ghazal & 0.171 & 0.376 & -0.002 & 0.003 & 2,292 \\
\hline Western Ec & atoria & 0.183 & 0.387 & -0.001 & 0.003 & 2,292 \\
\hline
\end{tabular}

Note: Differences between attritors and non-attritors in baseline characteristics estimated by an OLS on the attrition dummy and strata fixed effects. Standard errors are clustered at boma level. $\left.*^{* *},{ }^{* *}\right)$ indicates statistical significance at the tenpercent (five-percent, one-percent) level. 
Table A1.3: Attrition - Baseline difference between attritors from original control vs attritors original treatment group

\begin{tabular}{|c|c|c|c|c|c|c|}
\hline & & \multicolumn{2}{|c|}{ Control group } & \multicolumn{2}{|c|}{ ITT group } & \multirow[t]{2}{*}{$\mathrm{N}$} \\
\hline & & Mean & SD & Coeff. & SE & \\
\hline \multicolumn{7}{|c|}{ Individual and household characteristics } \\
\hline \multicolumn{2}{|l|}{ Age } & 27.226 & 5.186 & 0.387 & 0.363 & 769 \\
\hline \multicolumn{2}{|l|}{ Married } & 0.670 & 0.471 & -0.026 & 0.031 & 768 \\
\hline \multicolumn{2}{|c|}{ Employment status } & 0.644 & 0.479 & -0.050 & 0.036 & 769 \\
\hline \multicolumn{2}{|c|}{ Business ownership } & 0.670 & 0.471 & -0.022 & 0.031 & 769 \\
\hline \multicolumn{2}{|c|}{ Consumption food } & 5.223 & 1.334 & 0.136 & 0.086 & 769 \\
\hline \multicolumn{2}{|c|}{ Consumption nonfood } & 2.447 & 1.287 & -0.043 & 0.099 & 769 \\
\hline \multicolumn{2}{|c|}{ Formal bank account } & 0.322 & 0.468 & 0.016 & 0.030 & 769 \\
\hline \multicolumn{2}{|c|}{ (Log) amount formal loans } & -0.386 & 1.859 & -0.176 & 0.148 & 765 \\
\hline \multicolumn{2}{|c|}{ (Log) amount informal loans } & -1.017 & 2.913 & -0.220 & 0.212 & 758 \\
\hline \multirow{5}{*}{$\begin{array}{l}\text { Education } \\
\text { level }\end{array}$} & No education & 0.190 & 0.393 & -0.023 & 0.024 & 769 \\
\hline & Some Primary & 0.340 & 0.474 & 0.034 & 0.031 & 769 \\
\hline & Some & 0.410 & 0.493 & -0.017 & 0.029 & 769 \\
\hline & Secondary & & & & & \\
\hline & $\begin{array}{l}\text { Some University } \\
\text { or Higher }\end{array}$ & 0.060 & 0.237 & 0.006 & 0.015 & 769 \\
\hline \multirow[t]{3}{*}{ Literacy } & No English & 0.249 & 0.433 & -0.009 & 0.032 & 769 \\
\hline & Some English & 0.249 & 0.433 & $0.062 * *$ & 0.030 & 769 \\
\hline & Good English & 0.501 & 0.501 & -0.052 & 0.033 & 769 \\
\hline \multirow[t]{3}{*}{ Numeracy } & Low & 0.231 & 0.422 & -0.012 & 0.026 & 769 \\
\hline & Medium & 0.190 & 0.393 & 0.008 & 0.030 & 769 \\
\hline & High & 0.579 & 0.494 & 0.003 & 0.035 & 769 \\
\hline \multicolumn{2}{|c|}{ Household size } & 7.182 & 3.463 & -0.143 & 0.258 & 769 \\
\hline \multicolumn{2}{|c|}{ Number of children } & 3.026 & 2.301 & 0.069 & 0.168 & 769 \\
\hline \multicolumn{2}{|c|}{ Number of elderly } & 0.117 & 0.360 & -0.036 & 0.023 & 769 \\
\hline \multicolumn{2}{|c|}{ Number of rooms } & 3.091 & 1.784 & -0.070 & 0.099 & 769 \\
\hline \multicolumn{2}{|c|}{ Number of buildings } & 3.670 & 1.836 & -0.111 & 0.112 & 769 \\
\hline \multicolumn{2}{|c|}{ (Log) distance to KCB branch } & 0.174 & 0.380 & -0.012 & 0.011 & 769 \\
\hline \multicolumn{2}{|c|}{$\begin{array}{l}\text { Conflict exposure 2011-2014 } \\
\text { (300km buffer) }\end{array}$} & 0.003 & 1.177 & -0.051 & 0.061 & 769 \\
\hline \multicolumn{2}{|c|}{$\begin{array}{l}\text { Conflict exposure 2015-2017 } \\
\text { (300km buffer) }\end{array}$} & -0.004 & 1.130 & 0.011 & 0.068 & 769 \\
\hline \multicolumn{7}{|c|}{ State at baseline } \\
\hline \multicolumn{2}{|c|}{ Central Equatoria } & 0.169 & 0.375 & -0.000 & 0.000 & 769 \\
\hline \multicolumn{2}{|c|}{ Eastern Equatoria } & 0.164 & 0.370 & 0.003 & 0.003 & 769 \\
\hline Lakes & & 0.174 & 0.380 & 0.008 & 0.007 & 769 \\
\hline Northern B & Ir El Ghazal & 0.148 & 0.356 & 0.000 & 0.004 & 769 \\
\hline Western Ba & r El Ghazal & 0.171 & 0.377 & 0.000 & 0.004 & 769 \\
\hline Western Eq & atoria & 0.169 & 0.375 & -0.000 & 0.000 & 769 \\
\hline
\end{tabular}

Note: Differences between the original control vs ITT group in baseline characteristics estimated by an OLS on the ITT group dummy and strata fixed effects. Standard errors are clustered at boma level. * $(* *, * * *)$ indicates statistical significance at the ten-percent (five-percent, one-percent) level. 
Appendix 2 - Robustness Checks Tables

Table A2.1 Lee bounds for the intention-to-treat effects on main socio-economic outcomes

(1)

Lower bound

\begin{tabular}{lcc} 
& Lower bound & Upper bound \\
\hline & Main outcomes & Socio-economic \\
\hline Employment index & 0.045 & 0.047 \\
& $(0.610)$ & $(0.810)$ \\
Consumption index & 0.093 & 0.098 \\
& $(0.173)$ & $(0.538)$ \\
Savings, investment and debt & $0.261^{* *}$ & $0.268^{* *}$ \\
index & $(0.031)$ & $(0.047)$ \\
Business skills index & 0.007 & 0.009 \\
& $(0.942)$ & $(0.926)$ \\
\hline Observations & \multicolumn{3}{c}{2292} \\
\hline
\end{tabular}

Note: Outcome variables are listed on the left. Column (1) reports the lower bound. Column (2) reports the upper bound. P-values are in parenthesis displayed below the estimated coefficients. ${ }^{*}\left({ }^{*},{ }^{* *}\right)$ indicates statistical significance at the ten-percent (five-percent, one-percent) level. 
Table A2.2 Lee bounds for the intention-to-treat effects on main psychological and behavioral outcomes

(1)

(2)

Lower bound

Upper bound

\begin{tabular}{|c|c|c|}
\hline \multicolumn{3}{|c|}{ Main outcomes (survey-based) - Psychological and behavioral } \\
\hline & -0.005 & -0.002 \\
\hline Psychological wellbeing index & $(0.961)$ & (0.989) \\
\hline \multirow[t]{2}{*}{ Risk index } & -0.052 & -0.049 \\
\hline & $(0.595)$ & $(0.645)$ \\
\hline \multirow[t]{2}{*}{ Trust index } & -0.055 & -0.050 \\
\hline & $(0.590)$ & $(0.641)$ \\
\hline \multirow[t]{2}{*}{ Crime and violence index } & $-0.253 * * *$ & -0.105 \\
\hline & $(0.000)$ & $(0.553)$ \\
\hline \multirow[t]{2}{*}{ Migration index } & -0.027 & -0.027 \\
\hline & $(0.641)$ & $(0.826)$ \\
\hline Observations & \multicolumn{2}{|c|}{2292} \\
\hline
\end{tabular}

Note: Outcome variables are listed on the left. Column (1) reports the lower bound. Column (2) reports the upper bound. P-values are in parenthesis displayed below the estimated coefficients. ${ }^{*}(* *, * *)$ indicates statistical significance at the ten-percent (five-percent, one-percent) level. 
Table A2.3 Weighted Intention-to-treat effects of the original intervention on main socio-economic outcomes.

\begin{tabular}{|c|c|c|}
\hline & $\begin{array}{c}(1) \\
\text { ITT } \\
\text { (no controls) }\end{array}$ & $\begin{array}{c}\text { (2) } \\
\text { ITT } \\
\text { (controls) }\end{array}$ \\
\hline \multicolumn{3}{|c|}{ Main outcomes - Socio-economic } \\
\hline Employment index & $\begin{array}{c}0.065 \\
(0.285)\end{array}$ & $\begin{array}{c}0.075 \\
(0.211)\end{array}$ \\
\hline Consumption index & $\begin{array}{c}0.095 \\
(0.146)\end{array}$ & $\begin{array}{c}0.094 \\
(0.146)\end{array}$ \\
\hline $\begin{array}{l}\text { Savings, investment and debt } \\
\text { index }\end{array}$ & $\begin{array}{c}0.266^{* * *} \\
(0.000)\end{array}$ & $\begin{array}{c}0.265^{* * *} \\
(0.000)\end{array}$ \\
\hline Business skills index & $\begin{array}{c}0.012 \\
(0.814) \\
\end{array}$ & $\begin{array}{c}0.018 \\
(0.744) \\
\end{array}$ \\
\hline Observations & 1523 & 1507 \\
\hline
\end{tabular}

Note: Observations are weighted by their inverse likelihood to be in the final sample, based on who was easy to reach during the phone survey. All regression control for gender-state fixed effects. Control variables of column (2) include all baseline controls that were significant determinants of attrition and of selection between receiving "training and grant" vs "training, but no grant". In particular, these are age, marital status, employment status, business ownership, food consumption, non-food consumption, formal bank account, formal loans, informal loans, education level, literacy level, numeracy level, household size, number of children, number of rooms, number of buildings at baseline, and exposure to conflict events between baseline and endline. $P$-values are in parenthesis displayed below the estimated coefficients. $\left.{ }^{* * *}, * * *\right)$ indicates statistical significance at the tenpercent (five-percent, one-percent) level. 
Table A2.4 Weighted Intention-to-treat effects of the original intervention on main psychological and behavioral outcomes.

\begin{tabular}{lcc} 
& $(1)$ & $(2)$ \\
& ITT & ITT \\
& (no controls) & (controls) \\
\hline \multicolumn{3}{c}{ Main outcomes - Psychological and behavioral } \\
\hline & -0.036 & -0.022 \\
Psychological wellbeing index & $(0.476)$ & $(0.646)$ \\
Risk index & -0.054 & -0.062 \\
& $(0.394)$ & $(0.292)$ \\
Trust index & -0.013 & -0.033 \\
& $(0.811)$ & $(0.548)$ \\
Crime and violence index & $-0.110^{* *}$ & $-0.119 * *$ \\
& $(0.029)$ & $(0.023)$ \\
Migration index & -0.045 & -0.036 \\
& $(0.363)$ & $(0.482)$ \\
List experiment cattle index & $0.215^{* *}$ & $0.210^{* *}$ \\
& $(0.034)$ & $(0.037)$ \\
List experiment argument index & -0.125 & -0.120 \\
& $(0.179)$ & $(0.201)$ \\
\hline Observations & & 1495 \\
& 1523 &
\end{tabular}

Note: Observations are weighted by their inverse likelihood to be in the final sample, based on who was easy to reach during the phone survey. All regression control for gender-state fixed effects. Control variables of column (2) include all baseline controls that were significant determinants of attrition and of selection between receiving "training and grant" vs "training, but no grant". In particular, these are age, marital status, employment status, business ownership, food consumption, non-food consumption, formal bank account, formal loans, informal loans, education level, literacy level, numeracy level, household size, number of children, number of rooms, and number of buildings at baseline. P-values are in parenthesis displayed below the estimated coefficients. * ${ }^{* *}$, ***) indicates statistical significance at the ten-percent (five-percent, one-percent) level. 
Table A2.5 Weighted TOT and ATE estimates of the "training and grant" vs "training, but no grant" on main socio-economic

\begin{tabular}{|c|c|c|c|c|c|c|c|}
\hline \multicolumn{8}{|c|}{ outcomes } \\
\hline & & (1) & $(2)$ & (3) & (4) & (5) & (6) \\
\hline & & $\begin{array}{c}\text { TOT } \\
\text { (no } \\
\text { controls) }\end{array}$ & $\begin{array}{c}\text { TOT } \\
\text { (controls) }\end{array}$ & $\begin{array}{c}\text { TOT } \\
\text { (controls + } \\
\text { geography } \\
\text { controls) }\end{array}$ & $\begin{array}{c}\text { LATE } \\
\text { (no } \\
\text { controls) }\end{array}$ & $\begin{array}{c}\text { LATE } \\
\text { (controls) }\end{array}$ & $\begin{array}{c}\text { LATE } \\
\text { (controls + } \\
\text { geography } \\
\text { controls) }\end{array}$ \\
\hline \multicolumn{8}{|c|}{ Main outcomes - Socio-economic } \\
\hline \multirow{4}{*}{$\begin{array}{l}\text { Employment } \\
\text { index }\end{array}$} & Training, & 0.090 & $0.095^{*}$ & 0.059 & -0.011 & 0.011 & -0.016 \\
\hline & no grant & $(0.126)$ & $(0.093)$ & $(0.593)$ & $(0.957)$ & $(0.958)$ & $(0.956)$ \\
\hline & $\begin{array}{l}\text { Training } \\
\text { and }\end{array}$ & 0.040 & 0.051 & 0.019 & 0.277 & 0.262 & 0.165 \\
\hline & grant & $(0.717)$ & $(0.649)$ & $(0.903)$ & $(0.506)$ & $(0.503)$ & $(0.664)$ \\
\hline \multirow{4}{*}{$\begin{array}{l}\text { Consumption } \\
\text { index }\end{array}$} & Training, & 0.009 & 0.004 & -0.060 & $-0.434 * *$ & $-0.374 * *$ & -0.280 \\
\hline & no grant & $(0.889)$ & $(0.953)$ & $(0.605)$ & $(0.019)$ & $(0.038)$ & $(0.372)$ \\
\hline & $\begin{array}{l}\text { Training } \\
\text { and }\end{array}$ & $0.194^{* *}$ & $0.174 *$ & 0.134 & $1.145^{* *}$ & $1.017^{* *}$ & $0.986 * *$ \\
\hline & grant & $(0.029)$ & $(0.052)$ & $(0.340)$ & $(0.026)$ & $(0.027)$ & $(0.021)$ \\
\hline \multirow{4}{*}{$\begin{array}{l}\text { Savings, } \\
\text { investment } \\
\text { and debt } \\
\text { index }\end{array}$} & Training, & $0.200 * * *$ & $0.186 * * *$ & 0.107 & -0.194 & -0.207 & -0.283 \\
\hline & no grant & $(0.000)$ & $(0.001)$ & $(0.203)$ & $(0.219)$ & $(0.218)$ & $(0.327)$ \\
\hline & $\begin{array}{c}\text { Training } \\
\text { and }\end{array}$ & $0.460 * * *$ & $0.444^{* * *}$ & $0.360 * * *$ & $1.349 * * *$ & $1.356 * * *$ & $1.161^{* * *}$ \\
\hline & grant & $(0.000)$ & $(0.000)$ & $(0.000)$ & $(0.000)$ & $(0.000)$ & $(0.002)$ \\
\hline \multirow{4}{*}{$\begin{array}{l}\text { Business skills } \\
\text { index }\end{array}$} & Training, & -0.038 & -0.038 & -0.025 & -0.122 & 0.002 & 0.098 \\
\hline & no grant & $(0.524)$ & $(0.524)$ & $(0.690)$ & $(0.528)$ & (0.993) & $(0.727)$ \\
\hline & $\begin{array}{l}\text { Training } \\
\text { and }\end{array}$ & $0.294 * * *$ & $0.294 * * *$ & $0.274 * * *$ & 0.275 & 0.050 & 0.004 \\
\hline & grant & $(0.000)$ & $(0.000)$ & $(0.001)$ & $(0.453)$ & $(0.901)$ & $(0.991)$ \\
\hline Observations & & 1,500 & 1,495 & 1,474 & 1,500 & 1,474 & 1,474 \\
\hline F-stat & & & & & 20.62 & 18.22 & 34.41 \\
\hline
\end{tabular}

Note: Observations are weighted by their inverse likelihood to be in the final sample, based on who was easy to reach during the phone survey. All regression control for gender-state fixed effects. Control variables of column (2) include all baseline controls that were significant determinants of attrition and of selection between receiving "training and grant" vs "training, but no grant". In particular, these are age, marital status, employment status, business ownership, food consumption, non-food consumption, formal bank account, formal loans, informal loans, education level, literacy level, numeracy level, household size, number of children, number of rooms, number of buildings at baseline, and exposure to conflict events between baseline and endline. Column (3) also controls for geographic features since the estimation strategy relies on the distance to the closest KCB bank branch that might correlate with other geographic characteristics. Geography controls include distance to the closest city, distance to the closest road, average land gradient and their respective interactions with selection to the original treatment group, and the interaction between conflict exposure and the original treatment group. $P$ values are in parenthesis displayed below the estimated coefficients. ${ }^{*}\left(*,{ }^{* * *}\right)$ indicates statistical significance at the ten-percent (five-percent, one-percent) level. 


\begin{tabular}{|c|c|c|c|c|c|c|c|}
\hline & & $\begin{array}{c}(1) \\
\text { TOT } \\
\text { (no } \\
\text { controls) }\end{array}$ & $\begin{array}{c}(2) \\
\text { TOT } \\
\text { (controls) }\end{array}$ & $\begin{array}{c}\text { (3) } \\
\text { TOT } \\
\text { (controls + } \\
\text { geography } \\
\text { controls) }\end{array}$ & $\begin{array}{c}\text { (4) } \\
\text { LATE } \\
\text { (no } \\
\text { controls) }\end{array}$ & $\begin{array}{c}\text { (5) } \\
\text { LATE } \\
\text { (controls) }\end{array}$ & $\begin{array}{c}\text { (6) } \\
\text { LATE } \\
\text { (controls + } \\
\text { geography } \\
\text { controls) }\end{array}$ \\
\hline & \multicolumn{7}{|c|}{ Main outcomes (survey-based) - Psychological and behavioral } \\
\hline \multirow{4}{*}{$\begin{array}{l}\text { Psychological } \\
\text { wellbeing } \\
\text { index }\end{array}$} & Training, & 0.018 & 0.020 & 0.111 & -0.285 & -0.100 & 0.179 \\
\hline & no grant & $(0.751)$ & $(0.701)$ & $(0.214)$ & $(0.115)$ & $(0.582)$ & $(0.429)$ \\
\hline & $\begin{array}{c}\text { Training } \\
\text { and }\end{array}$ & -0.005 & -0.044 & 0.053 & 0.400 & 0.093 & $0.779 * *$ \\
\hline & grant & $(0.945)$ & $(0.554)$ & $(0.578)$ & $(0.268)$ & (0.789) & $(0.017)$ \\
\hline \multirow[t]{4}{*}{ Risk index } & Training, & 0.007 & -0.014 & 0.056 & -0.425 & -0.381 & -0.146 \\
\hline & no grant & $(0.925)$ & $(0.868)$ & $(0.617)$ & $(0.127)$ & $(0.146)$ & $(0.712)$ \\
\hline & $\begin{array}{c}\text { Training } \\
\text { and }\end{array}$ & -0.097 & -0.104 & -0.025 & 0.625 & 0.508 & 0.639 \\
\hline & grant & $(0.211)$ & (0.187) & $(0.806)$ & $(0.264)$ & $(0.328)$ & (0.129) \\
\hline \multirow[t]{4}{*}{ Trust index } & Training, & -0.059 & -0.075 & -0.014 & -0.070 & -0.077 & $-0.471^{*}$ \\
\hline & no grant & $(0.337)$ & $(0.240)$ & $(0.903)$ & $(0.752)$ & $(0.740)$ & $(0.082)$ \\
\hline & $\begin{array}{c}\text { Training } \\
\text { and }\end{array}$ & $0.174 * *$ & $0.177^{* *}$ & $0.253 * *$ & 0.072 & 0.028 & 0.023 \\
\hline & grant & $(0.041)$ & $(0.036)$ & $(0.040)$ & $(0.856)$ & $(0.946)$ & $(0.950)$ \\
\hline \multirow{4}{*}{$\begin{array}{l}\text { Crime and } \\
\text { violence index }\end{array}$} & Training, & -0.094 & $-0.105^{*}$ & -0.030 & $-0.514^{*}$ & $-0.603^{*}$ & -0.278 \\
\hline & no grant & $(0.118)$ & $(0.091)$ & $(0.712)$ & $(0.097)$ & $(0.067)$ & $(0.408)$ \\
\hline & $\begin{array}{c}\text { Training } \\
\text { and }\end{array}$ & $-0.123 *$ & $-0.128 *$ & -0.096 & 0.557 & 0.682 & 0.427 \\
\hline & grant & $(0.091)$ & $(0.086)$ & $(0.302)$ & $(0.290)$ & (0.217) & (0.287) \\
\hline \multirow{4}{*}{$\begin{array}{l}\text { Migration } \\
\text { index }\end{array}$} & $\begin{array}{l}\text { Training, } \\
\text { no grant }\end{array}$ & -0.083 & -0.085 & -0.134 & -0.246 & -0.286 & -0.397 \\
\hline & & $(0.125)$ & $(0.128)$ & (0.113) & $(0.183)$ & (0.154) & $(0.160)$ \\
\hline & $\begin{array}{c}\text { Training } \\
\text { and }\end{array}$ & -0.006 & -0.018 & -0.066 & 0.355 & 0.455 & -0.029 \\
\hline & grant & $(0.947)$ & $(0.821)$ & $(0.473)$ & $(0.369)$ & $(0.272)$ & $(0.935)$ \\
\hline \multirow{4}{*}{$\begin{array}{l}\text { List } \\
\text { experiment } \\
\text { cattle index }\end{array}$} & $\begin{array}{l}\text { Training, } \\
\text { no grant }\end{array}$ & $0.247^{* *}$ & $0.257^{* *}$ & $0.282 * *$ & 0.108 & 0.143 & 0.182 \\
\hline & & $(0.021)$ & $(0.031)$ & $(0.020)$ & $(0.666)$ & $(0.627)$ & $(0.533)$ \\
\hline & $\begin{array}{c}\text { Training } \\
\text { and }\end{array}$ & -0.032 & -0.044 & -0.018 & 0.410 & 0.484 & 0.471 \\
\hline & grant & $(0.832)$ & $(0.593)$ & $(0.841)$ & $(0.457)$ & $(0.443)$ & $(0.445)$ \\
\hline \multirow{4}{*}{$\begin{array}{l}\text { List } \\
\text { experiment } \\
\text { argument } \\
\text { index }\end{array}$} & $\begin{array}{l}\text { Training, } \\
\text { no grant }\end{array}$ & -0.134 & -0.109 & -0.147 & $-0.431^{*}$ & -0.282 & -0.291 \\
\hline & & $(0.190)$ & $(0.301)$ & (0.168) & $(0.060)$ & (0.188) & $(0.160)$ \\
\hline & $\begin{array}{c}\text { Training } \\
\text { and }\end{array}$ & -0.208 & -0.232 & -0.212 & 0.400 & 0.093 & 0.071 \\
\hline & grant & $(0.186)$ & (0.167) & $(0.200)$ & $(0.432)$ & $(0.856)$ & $(0.889)$ \\
\hline Observations & & 1,500 & 1495 & 1474 & 1,500 & 1,474 & 1,474 \\
\hline F-stat & & & & & 20.62 & 18.37 & 34.65 \\
\hline
\end{tabular}

Note: Observations are weighted by their inverse likelihood to be in the final sample, based on who was easy to reach during the phone survey. All regression control for gender-state fixed effects. Control variables of column (2) include all baseline controls that were significant determinants of attrition and of selection between receiving "training and grant" vs "training, but no grant". In particular, these are age, marital status, employment status, business ownership, food consumption, non-food consumption, formal bank account, formal loans, informal loans, education level, literacy level, numeracy level, household size, number of children, number of rooms, number of buildings at baseline, and exposure to conflict events between baseline and endline. Column (3) also controls for geographic features since the estimation strategy relies on the distance to the closest KCB bank branch that might correlate with other geographic characteristics. Geography controls include distance to the closest city, distance to the closest road, average land gradient and their respective interactions with selection to the original treatment group, and the interaction of conflict exposure and the original treatment group. P-values are in parenthesis displayed below the estimated coefficients. ${ }^{*}(* *, * *)$ indicates statistical significance at the ten-percent (five-percent, one-percent) level. 


\section{Appendix 3 - Gender heterogeneity}

Table A3.1 Intention-to-treat effects of the original intervention on main socio-economic outcomes by gender

\begin{tabular}{|c|c|c|c|c|c|}
\hline & $(1)$ & $(2)$ & (3) & (4) & $(5)$ \\
\hline & \multicolumn{2}{|c|}{ ITT for males } & \multicolumn{2}{|c|}{ ITT for females } & \multirow{2}{*}{$\begin{array}{c}\text { Coefficient } \\
\text { equality (2) vs (4) }\end{array}$} \\
\hline & (no controls) & (controls) & (no controls) & (controls) & \\
\hline \multicolumn{6}{|c|}{ Main outcomes - Socioeconomic } \\
\hline Employment & 0.034 & 0.020 & 0.080 & 0.084 & 0.064 \\
\hline index & $(0.764)$ & $(0.847)$ & $(0.203)$ & $(0.176)$ & $(0.595)$ \\
\hline \multirow{2}{*}{$\begin{array}{l}\text { Consumption } \\
\text { index }\end{array}$} & 0.056 & 0.028 & $0.116^{*}$ & 0.110 & 0.082 \\
\hline & $(0.574)$ & $(0.783)$ & $(0.098)$ & $(0.117)$ & $(0.476)$ \\
\hline $\begin{array}{l}\text { Savings, } \\
\text { investment }\end{array}$ & $0.387^{* * *}$ & $0.349 * * *$ & $0.210 * * *$ & $0.209 * * *$ & -0.140 \\
\hline and debt & & & & & \\
\hline index & $(0.000)$ & $(0.000)$ & $(0.001)$ & $(0.001)$ & $(0.167)$ \\
\hline \multirow{2}{*}{$\begin{array}{l}\text { Business } \\
\text { skills index }\end{array}$} & 0.082 & 0.090 & -0.022 & -0.025 & -0.114 \\
\hline & $(0.263)$ & $(0.242)$ & $(0.736)$ & $(0.716)$ & $(0.241)$ \\
\hline Observations & 555 & 547 & 968 & & \\
\hline
\end{tabular}

Note: P-values are in parenthesis displayed below the estimated coefficients. * (**, ***) indicates statistical significance at the ten-percent (five-percent, one-percent) level. All regression control for gender-state fixed effects. Control variables of column (2) include all baseline controls that were significant determinants of attrition and of selection between receiving "training and grant" vs "training, but no grant". In particular, these are age, marital status, employment status, business ownership, food consumption, non-food consumption, formal bank account, formal loans, informal loans, education level, literacy level, numeracy level, household size, number of children, number of rooms, number of buildings at baseline, and exposure to conflict events between baseline and endline. Column (5) reports tests for coefficient equality between estimates from males and females in column (2) and (4). Displayed are differences of coefficient p-values of the test in parenthesis. 
able A3.2 Intention-to-treat effects of the original intervention on main psychological and behavioral outcomes by gender

\begin{tabular}{|c|c|c|c|c|c|}
\hline & $(1)$ & $(2)$ & (3) & $(4)$ & $(5)$ \\
\hline & \multicolumn{2}{|c|}{ ITT for males } & \multicolumn{2}{|c|}{ ITT for females } & \multirow{2}{*}{$\begin{array}{c}\text { Coefficient } \\
\text { equality (2) vs (4) }\end{array}$} \\
\hline & (no controls) & (controls) & (no controls) & (controls) & \\
\hline \multicolumn{6}{|c|}{ Main outcomes - Psychological and behavioral } \\
\hline & 0.099 & 0.079 & -0.071 & -0.045 & -0.125 \\
\hline Psychological wellbeing index & $(0.204)$ & $(0.306)$ & $(0.216)$ & $(0.414)$ & $(0.190)$ \\
\hline \multirow[t]{2}{*}{ Risk index } & 0.004 & -0.003 & -0.069 & -0.061 & -0.058 \\
\hline & $(0.960)$ & $(0.964)$ & $(0.391)$ & $(0.430)$ & $(0.565)$ \\
\hline \multirow[t]{2}{*}{ Trust index } & 0.038 & -0.004 & -0.076 & -0.102 & -0.098 \\
\hline & $(0.653)$ & $(0.963)$ & $(0.235)$ & $(0.127)$ & $(0.407)$ \\
\hline \multirow[t]{2}{*}{ Crime and violence index } & 0.007 & 0.007 & $-0.129 * *$ & $-0.152 * *$ & $-0.159 *$ \\
\hline & (0.939) & $(0.927)$ & $(0.024)$ & $(0.011)$ & $(0.087)$ \\
\hline \multirow[t]{2}{*}{ Migration index } & -0.050 & -0.002 & -0.013 & -0.025 & -0.022 \\
\hline & $(0.478)$ & $(0.975)$ & $(0.845)$ & $(0.716)$ & $(0.834)$ \\
\hline \multicolumn{6}{|c|}{ Main outcomes (experiments) - Psychological and behavioral } \\
\hline \multirow[t]{2}{*}{ List experiment cattle index } & $0.269 *$ & 0.258 & 0.108 & 0.117 & -0.142 \\
\hline & $(0.094)$ & $(0.174)$ & $(0.382)$ & $(0.206)$ & $(0.507)$ \\
\hline \multirow[t]{2}{*}{ List experiment argument index } & 0.140 & 0.135 & $-0.303 * *$ & $-0.304^{* *}$ & $-0.439 * *$ \\
\hline & $(0.378)$ & $(0.419)$ & $(0.017)$ & $(0.014)$ & $(0.038)$ \\
\hline Observations & 555 & 547 & 968 & 948 & \\
\hline
\end{tabular}

Note: P-values are in parenthesis displayed below the estimated coefficients. * $\left.{ }^{* *},{ }^{* * *}\right)$ indicates statistical significance at the ten-percent (five-percent, one-percent) level. All regression control for gender-state fixed effects. Control variables of column (2) include all baseline controls that were significant determinants of attrition and of selection between receiving "training and grant" vs "training, but no grant". In particular, these are age, marital status, employment status, business ownership, food consumption, non-

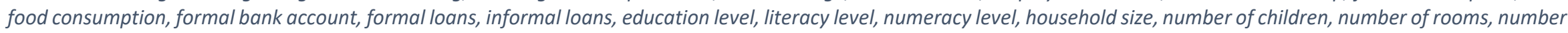
of buildings at baseline, and exposure to conflict events between baseline and endline. Column (5) reports tests for coefficient equality between estimates from males and females in column (2) and (4). Displayed are differences of coefficient p-values of the test in parenthesis. 
Table A3.3 Effects of the "training and grant" vs "training, but no grant" on main socio-economic outcomes by gender

\begin{tabular}{|c|c|c|c|c|c|c|c|c|c|c|c|c|c|c|}
\hline & & & & & \multirow[b]{2}{*}{ (13) } \\
\hline & & (1) & (2) & (3) & (4) & (5) & (6) & (7) & (8) & (9) & (10) & (11) & (12) & \\
\hline & & \multicolumn{3}{|c|}{ TOT for males } & \multicolumn{3}{|c|}{ LATE for males } & \multicolumn{3}{|c|}{ TOT for females } & \multicolumn{3}{|c|}{ LATE for females } & Coeff \\
\hline & & $\begin{array}{c}\text { (no } \\
\text { controls) }\end{array}$ & (controls) & $\begin{array}{l}\text { (controls } \\
+ \text { geo } \\
\text { controls) }\end{array}$ & $\begin{array}{c}\text { (no } \\
\text { controls) }\end{array}$ & (controls) & $\begin{array}{l}\text { (controls } \\
+ \text { geo } \\
\text { controls) }\end{array}$ & $\begin{array}{c}\text { (no } \\
\text { controls) }\end{array}$ & (controls) & $\begin{array}{l}\text { (controls } \\
+ \text { geo } \\
\text { controls) }\end{array}$ & $\begin{array}{c}\text { (no } \\
\text { controls) }\end{array}$ & (controls) & $\begin{array}{c}\text { controls } \\
+ \text { geo } \\
\text { controls) }\end{array}$ & $\begin{array}{c}\text { equality } \\
\text { (6) vs } \\
(12)\end{array}$ \\
\hline \multirow{3}{*}{$\begin{array}{l}\text { Employment } \\
\text { index }\end{array}$} & Training, & -0.025 & -0.064 & $-0.416^{*}$ & 0.105 & -0.001 & -0.505 & $0.145 * *$ & $0.152 * *$ & $0.273 * *$ & -0.131 & -0.049 & 0.454 & 0.959 \\
\hline & no grant & $(0.850)$ & $(0.601)$ & $(0.066)$ & $(0.781)$ & $(0.998)$ & $(0.444)$ & $(0.017)$ & $(0.010)$ & $(0.010)$ & $(0.581)$ & $(0.807)$ & $(0.139)$ & $(0.173)$ \\
\hline & $\begin{array}{l}\text { Training } \\
\text { and } \\
\text { grant }\end{array}$ & $\begin{array}{l}-0.095 \\
(0.542)\end{array}$ & $\begin{array}{l}-0.104 \\
(0.495)\end{array}$ & $\begin{array}{l}-0.471^{*} \\
(0.072)\end{array}$ & $\begin{array}{l}-0.040 \\
(0.952)\end{array}$ & $\begin{array}{c}0.074 \\
(0.901)\end{array}$ & $\begin{array}{l}-0.374 \\
(0.506)\end{array}$ & $\begin{array}{c}0.158 \\
(0.258)\end{array}$ & $\begin{array}{c}0.169 \\
(0.228)\end{array}$ & $\begin{array}{l}0.286^{*} \\
(0.087)\end{array}$ & $\begin{array}{c}0.637 \\
(0.191)\end{array}$ & $\begin{array}{c}0.456 \\
(0.284)\end{array}$ & $\begin{array}{l}0.750^{*} \\
(0.096)\end{array}$ & $\begin{array}{c}1.124 \\
(0.124)\end{array}$ \\
\hline \multirow{3}{*}{$\begin{array}{l}\text { Consumption } \\
\text { index }\end{array}$} & Training, & 0.069 & 0.058 & 0.187 & -0.323 & -0.319 & 0.326 & 0.032 & 0.017 & -0.072 & $-0.374 *$ & -0.303 & -0.543 & -0.870 \\
\hline & no grant & $(0.524)$ & $(0.605)$ & $(0.317)$ & $(0.307)$ & $(0.327)$ & $(0.483)$ & $(0.674)$ & $(0.837)$ & $(0.610)$ & $(0.067)$ & $(0.133)$ & $(0.236)$ & $(0.213)$ \\
\hline & $\begin{array}{c}\text { Training } \\
\text { and } \\
\text { grant }\end{array}$ & $\begin{array}{c}0.058 \\
(0.623)\end{array}$ & $\begin{array}{c}0.029 \\
(0.812)\end{array}$ & $\begin{array}{c}0.164 \\
(0.467)\end{array}$ & $\begin{array}{c}0.616 \\
(0.302)\end{array}$ & $\begin{array}{c}0.521 \\
(0.361)\end{array}$ & $\begin{array}{l}0.785 * \\
(0.100)\end{array}$ & $\begin{array}{c}0.264 * * * \\
(0.008)\end{array}$ & $\begin{array}{l}0.248^{* *} \\
(0.012)\end{array}$ & $\begin{array}{l}0.242^{*} \\
(0.059)\end{array}$ & $\begin{array}{l}1.241^{* *} \\
(0.025)\end{array}$ & $\begin{array}{l}1.073 * * \\
(0.036)\end{array}$ & $\begin{array}{c}0.750 \\
(0.122)\end{array}$ & $\begin{array}{l}-0.035 \\
(0.959)\end{array}$ \\
\hline \multirow{2}{*}{$\begin{array}{l}\text { Savings, } \\
\text { investment } \\
\text { and debt } \\
\text { index }\end{array}$} & $\begin{array}{l}\text { Training, } \\
\text { no grant }\end{array}$ & $\begin{array}{c}0.373^{* * * *} \\
(0.001)\end{array}$ & $\begin{array}{c}0.303^{* * *} \\
(0.006)\end{array}$ & $\begin{array}{c}0.114 \\
(0.453)\end{array}$ & $\begin{array}{l}-0.429 \\
(0.203)\end{array}$ & $\begin{array}{c}-0.450 \\
(0.174)\end{array}$ & $\begin{array}{l}-0.561 \\
(0.200)\end{array}$ & $\begin{array}{c}0.140 * * \\
(0.014)\end{array}$ & $\begin{array}{c}0.135^{* *} \\
(0.018)\end{array}$ & $\begin{array}{c}0.104 \\
(0.343)\end{array}$ & $\begin{array}{l}-0.049 \\
(0.768)\end{array}$ & $\begin{array}{c}-0.021 \\
(0.898)\end{array}$ & $\begin{array}{l}-0.286 \\
(0.421)\end{array}$ & $\begin{array}{c}0.275 \\
(0.592)\end{array}$ \\
\hline & $\begin{array}{c}\text { Training } \\
\text { and } \\
\text { grant }\end{array}$ & $\begin{array}{c}0.408^{* * *} \\
(0.002)\end{array}$ & $\begin{array}{c}0.388^{* * *} \\
(0.001)\end{array}$ & $\begin{array}{c}0.205 \\
(0.211)\end{array}$ & $\begin{array}{c}1.715^{* * *} \\
(0.008)\end{array}$ & $\begin{array}{c}1.603^{* * *} \\
(0.008)\end{array}$ & $\begin{array}{l}1.029 * * \\
(0.027)\end{array}$ & $\begin{array}{c}0.460 * * * \\
(0.000)\end{array}$ & $\begin{array}{c}0.439 * * * \\
(0.000)\end{array}$ & $\begin{array}{c}0.421^{* * *} \\
(0.000)\end{array}$ & $\begin{array}{c}0.975^{* *} \\
(0.013)\end{array}$ & $\begin{array}{l}0.903^{* *} \\
(0.019)\end{array}$ & $\begin{array}{l}0.913^{*} \\
(0.065)\end{array}$ & $\begin{array}{l}-0.116 \\
(0.862)\end{array}$ \\
\hline \multirow[t]{2}{*}{$\begin{array}{l}\text { Business } \\
\text { skills index }\end{array}$} & $\begin{array}{l}\text { Training, } \\
\text { no grant }\end{array}$ & $\begin{array}{c}0.042 \\
(0.660)\end{array}$ & $\begin{array}{c}0.026 \\
(0.789)\end{array}$ & $\begin{array}{c}0.091 \\
(0.590)\end{array}$ & $\begin{array}{l}-0.046 \\
(0.895)\end{array}$ & $\begin{array}{l}-0.035 \\
(0.929)\end{array}$ & $\begin{array}{c}0.540 \\
(0.179)\end{array}$ & $\begin{array}{c}-0.070 \\
(0.313)\end{array}$ & $\begin{array}{c}-0.059 \\
(0.417)\end{array}$ & $\begin{array}{c}-0.013 \\
(0.922)\end{array}$ & $\begin{array}{c}-0.167 \\
(0.406)\end{array}$ & $\begin{array}{c}-0.016 \\
(0.941)\end{array}$ & $\begin{array}{c}0.058 \\
(0.898)\end{array}$ & $\begin{array}{c}-0.482 \\
(0.451)\end{array}$ \\
\hline & $\begin{array}{c}\text { Training } \\
\text { and } \\
\text { grant }\end{array}$ & $\begin{array}{c}0.285^{* *} \\
(0.019) \\
\end{array}$ & $\begin{array}{c}0.291^{* *} \\
(0.023) \\
\end{array}$ & $\begin{array}{l}0.357^{* *} \\
(0.041) \\
\end{array}$ & $\begin{array}{r}0.340 \\
(0.551) \\
\end{array}$ & $\begin{array}{c}0.320 \\
(0.603) \\
\end{array}$ & $\begin{array}{c}0.104 \\
(0.873) \\
\end{array}$ & $\begin{array}{l}0.212^{*} \\
(0.061)\end{array}$ & $\begin{array}{c}0.182 \\
(0.110) \\
\end{array}$ & $\begin{array}{l}0.269 * \\
(0.078)\end{array}$ & $\begin{array}{c}0.250 \\
(0.584) \\
\end{array}$ & $\begin{array}{l}-0.090 \\
(0.846)\end{array}$ & $\begin{array}{c}0.195 \\
(0.704) \\
\end{array}$ & $\begin{array}{r}0.092 \\
(0.924) \\
\end{array}$ \\
\hline Observations & & 555 & 547 & 541 & 547 & 541 & 541 & 968 & 948 & 933 & 953 & 933 & 933 & \\
\hline F-stat & & & & & 4.510 & 4.568 & 19.85 & & & & 5.330 & 5.268 & 15.76 & \\
\hline
\end{tabular}

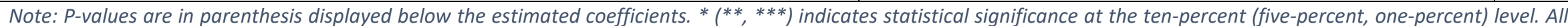

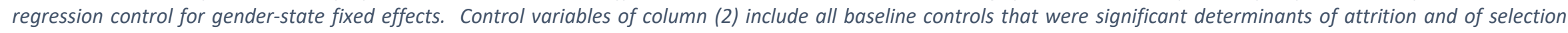
between receiving "training and grant" vs "training, but no grant". In particular, these are age, marital status, employment status, business ownership, food consumption, nonfood consumption, formal bank account, formal loans, informal loans, education level, literacy level, numeracy level, household size, number of children, number of rooms, number

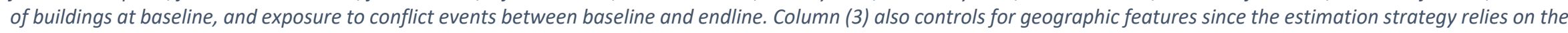
distance to the closest KCB bank branch that might correlate with other geographic characteristics. Geography controls include distance to the closest city, distance to the closest

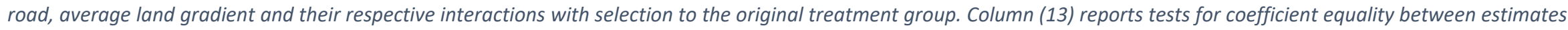
from males and females in column (6) and (12). Displayed are differences of coefficient p-values of the test in parenthesis. 


\begin{tabular}{|c|c|c|c|c|c|c|c|c|c|c|c|c|c|c|}
\hline & & \multicolumn{6}{|c|}{ ain psychological and behavioral outcomes by gend } & & & & & & & \\
\hline & & (1) & $(2)$ & (3) & (4) & (5) & (6) & (7) & (8) & (9) & $(10)$ & $(11)$ & $(12)$ & $(13)$ \\
\hline & & \multicolumn{3}{|c|}{ TOT for males } & \multicolumn{3}{|c|}{ LATE for males } & \multicolumn{3}{|c|}{ TOT for females } & \multicolumn{3}{|c|}{ LATE for females } & \multirow{2}{*}{$\begin{array}{l}\text { Coeff } \\
\text { equality } \\
\text { (6) vs (12) }\end{array}$} \\
\hline & & $\begin{array}{l}\text { (no } \\
\text { control } \\
\text { s) }\end{array}$ & $\begin{array}{l}\text { (contr } \\
\text { ols) }\end{array}$ & $\begin{array}{l}\text { (controls } \\
+ \text { geo } \\
\text { controls) }\end{array}$ & $\begin{array}{l}\text { (no } \\
\text { controls) }\end{array}$ & (controls) & $\begin{array}{l}\text { (controls } \\
+ \text { geo } \\
\text { controls) }\end{array}$ & $\begin{array}{l}\text { (no } \\
\text { controls) }\end{array}$ & (controls) & $\begin{array}{l}\text { (controls } \\
+ \text { geo } \\
\text { controls) }\end{array}$ & $\begin{array}{l}\text { (no } \\
\text { controls) }\end{array}$ & (controls) & $\begin{array}{l}\text { (controls + } \\
\text { geo } \\
\text { controls) }\end{array}$ & \\
\hline \multicolumn{15}{|c|}{ Main psychological and behavioral outcomes (survey measures) } \\
\hline \multirow{2}{*}{$\begin{array}{l}\text { Psychologic } \\
\text { al wellbeing } \\
\text { index }\end{array}$} & $\begin{array}{l}\text { Training, no } \\
\text { grant }\end{array}$ & $\begin{array}{l}0.108 \\
(0.303)\end{array}$ & $\begin{array}{l}0.079 \\
(0.475)\end{array}$ & $\begin{array}{l}0.170 \\
(0.366)\end{array}$ & $\begin{array}{l}-0.013 \\
(0.969)\end{array}$ & $\begin{array}{l}0.089 \\
(0.802)\end{array}$ & $\begin{array}{l}-0.159 \\
(0.721)\end{array}$ & $\begin{array}{l}-0.012 \\
(0.814)\end{array}$ & $\begin{array}{l}0.012 \\
(0.806)\end{array}$ & $\begin{array}{l}0.126 \\
(0.153)\end{array}$ & $\begin{array}{l}-0.370^{* *} \\
(0.042)\end{array}$ & $\begin{array}{l}-0.153 \\
(0.342)\end{array}$ & $\begin{array}{l}0.292 \\
(0.433)\end{array}$ & $\begin{array}{l}0.452 \\
(0.510)\end{array}$ \\
\hline & $\begin{array}{l}\text { Training and } \\
\text { grant }\end{array}$ & $\begin{array}{l}0.154 \\
(0.146)\end{array}$ & $\begin{array}{l}0.122 \\
(0.224)\end{array}$ & $\begin{array}{l}0.173 \\
(0.257)\end{array}$ & $\begin{array}{l}0.257 \\
(0.618)\end{array}$ & $\begin{array}{l}0.075 \\
(0.885)\end{array}$ & $\begin{array}{l}0.475 \\
(0.268)\end{array}$ & $\begin{array}{l}-0.059 \\
(0.538)\end{array}$ & $\begin{array}{l}-0.099 \\
(0.296)\end{array}$ & $\begin{array}{l}0.009 \\
(0.941)\end{array}$ & $\begin{array}{l}0.527 \\
(0.290)\end{array}$ & $\begin{array}{l}0.130 \\
(0.757)\end{array}$ & $\begin{array}{l}0.760 * \\
(0.081)\end{array}$ & $\begin{array}{l}0.285 \\
(0.671)\end{array}$ \\
\hline \multirow[t]{2}{*}{ Risk index } & $\begin{array}{l}\text { Training, no } \\
\text { grant }\end{array}$ & $\begin{array}{l}-0.117 \\
(0.197)\end{array}$ & $\begin{array}{l}-0.123 \\
(0.221)\end{array}$ & $\begin{array}{l}-0.160 \\
(0.305)\end{array}$ & $\begin{array}{l}-0.371 \\
(0.306)\end{array}$ & $\begin{array}{l}-0.438 \\
(0.238)\end{array}$ & $\begin{array}{l}0.265 \\
(0.569)\end{array}$ & $\begin{array}{l}0.088 \\
(0.389)\end{array}$ & $\begin{array}{l}0.077 \\
(0.493)\end{array}$ & $\begin{array}{l}0.208 \\
(0.120)\end{array}$ & $\begin{array}{l}-0.470 \\
(0.113)\end{array}$ & $\begin{array}{l}-0.366 \\
(0.147)\end{array}$ & $\begin{array}{l}-0.496 \\
(0.370)\end{array}$ & $\begin{array}{l}-0.761 \\
(0.168)\end{array}$ \\
\hline & $\begin{array}{l}\text { Training and } \\
\text { grant }\end{array}$ & $\begin{array}{l}0.087 \\
(0.468)\end{array}$ & $\begin{array}{l}0.069 \\
(0.552)\end{array}$ & $\begin{array}{l}0.061 \\
(0.693)\end{array}$ & $\begin{array}{l}0.577 \\
(0.333)\end{array}$ & $\begin{array}{l}0.639 \\
(0.290)\end{array}$ & $\begin{array}{l}0.529 \\
(0.255)\end{array}$ & $\begin{array}{l}-0.186 * * \\
(0.044)\end{array}$ & $\begin{array}{l}-0.170^{*} \\
(0.077)\end{array}$ & $\begin{array}{l}-0.030 \\
(0.804)\end{array}$ & $\begin{array}{l}0.792 \\
(0.235)\end{array}$ & $\begin{array}{l}0.605 \\
(0.294)\end{array}$ & $\begin{array}{l}0.698^{*} \\
(0.093)\end{array}$ & $\begin{array}{l}0.169 \\
(0.761)\end{array}$ \\
\hline \multirow[t]{2}{*}{ Trust index } & $\begin{array}{l}\text { Training, no } \\
\text { grant }\end{array}$ & $\begin{array}{l}-0.001 \\
(0.992)\end{array}$ & $\begin{array}{l}-0.062 \\
(0.556)\end{array}$ & $\begin{array}{l}0.213 \\
(0.352)\end{array}$ & $\begin{array}{l}-0.095 \\
(0.792)\end{array}$ & $\begin{array}{l}-0.133 \\
(0.729)\end{array}$ & $\begin{array}{l}0.402 \\
(0.467)\end{array}$ & $\begin{array}{l}-0.117^{*} \\
(0.096)\end{array}$ & $\begin{array}{l}-0.124^{*} \\
(0.098)\end{array}$ & $\begin{array}{l}-0.098 \\
(0.434)\end{array}$ & $\begin{array}{l}-0.012 \\
(0.948)\end{array}$ & $\begin{array}{l}-0.053 \\
(0.767)\end{array}$ & $\begin{array}{l}-0.896 * * * \\
(0.008)\end{array}$ & $\begin{array}{l}-1.298^{* *} \\
(0.049)\end{array}$ \\
\hline & $\begin{array}{l}\text { Training and } \\
\text { grant }\end{array}$ & $\begin{array}{l}0.257^{* *} \\
(0.047)\end{array}$ & $\begin{array}{l}0.238^{*} \\
(0.074)\end{array}$ & $\begin{array}{l}0.493^{* *} \\
(0.030)\end{array}$ & $\begin{array}{l}0.210 \\
(0.679)\end{array}$ & $\begin{array}{l}0.177 \\
(0.734)\end{array}$ & $\begin{array}{l}0.677 \\
(0.236)\end{array}$ & $\begin{array}{l}0.041 \\
(0.716)\end{array}$ & $\begin{array}{l}0.038 \\
(0.725)\end{array}$ & $\begin{array}{l}0.055 \\
(0.704)\end{array}$ & $\begin{array}{l}-0.277 \\
(0.557)\end{array}$ & $\begin{array}{l}-0.278 \\
(0.545)\end{array}$ & $\begin{array}{l}-0.791^{*} \\
(0.083)\end{array}$ & $\begin{array}{l}-1.468^{* *} \\
(0.042)\end{array}$ \\
\hline \multirow{2}{*}{$\begin{array}{l}\text { Crime and } \\
\text { violence } \\
\text { index }\end{array}$} & $\begin{array}{l}\text { Training, no } \\
\text { grant }\end{array}$ & $\begin{array}{l}0.093 \\
(0.499)\end{array}$ & $\begin{array}{l}0.082 \\
(0.508)\end{array}$ & $\begin{array}{l}-0.017 \\
(0.932)\end{array}$ & $\begin{array}{l}-0.371 \\
(0.332)\end{array}$ & $\begin{array}{l}-0.434 \\
(0.306)\end{array}$ & $\begin{array}{l}-0.309 \\
(0.561)\end{array}$ & $\begin{array}{l}-0.127 * * \\
(0.034)\end{array}$ & $\begin{array}{l}-0.151 * * \\
(0.018)\end{array}$ & $\begin{array}{l}-0.043 \\
(0.667)\end{array}$ & $\begin{array}{l}-0.543^{*} \\
(0.092)\end{array}$ & $\begin{array}{l}-0.642 * * \\
(0.044)\end{array}$ & $\begin{array}{l}-0.631 \\
(0.111)\end{array}$ & $\begin{array}{l}-0.321 \\
(0.605)\end{array}$ \\
\hline & $\begin{array}{l}\text { Training and } \\
\text { grant }\end{array}$ & $\begin{array}{l}-0.180 \\
(0.126)\end{array}$ & $\begin{array}{l}-0.176 \\
(0.163)\end{array}$ & $\begin{array}{l}-0.262 \\
(0.218)\end{array}$ & $\begin{array}{l}0.625 \\
(0.324)\end{array}$ & $\begin{array}{l}0.669 \\
(0.285)\end{array}$ & $\begin{array}{l}0.399 \\
(0.456)\end{array}$ & $\begin{array}{l}-0.042 \\
(0.663)\end{array}$ & $\begin{array}{l}-0.049 \\
(0.623)\end{array}$ & $\begin{array}{l}0.004 \\
(0.973)\end{array}$ & $\begin{array}{l}0.614 \\
(0.340)\end{array}$ & $\begin{array}{l}0.745 \\
(0.253)\end{array}$ & $\begin{array}{l}0.103 \\
(0.814)\end{array}$ & $\begin{array}{l}-0.296 \\
(0.662)\end{array}$ \\
\hline \multirow[t]{2}{*}{$\begin{array}{l}\text { Migration } \\
\text { index }\end{array}$} & $\begin{array}{l}\text { Training, no } \\
\text { grant }\end{array}$ & $\begin{array}{l}-0.147^{*} \\
(0.081)\end{array}$ & $\begin{array}{l}-0.098 \\
(0.287)\end{array}$ & $\begin{array}{l}-0.214 \\
(0.150)\end{array}$ & $\begin{array}{l}0.048 \\
(0.866)\end{array}$ & $\begin{array}{l}0.010 \\
(0.975)\end{array}$ & $\begin{array}{l}0.156 \\
(0.745)\end{array}$ & $\begin{array}{l}-0.045 \\
(0.552)\end{array}$ & $\begin{array}{l}-0.072 \\
(0.319)\end{array}$ & $\begin{array}{l}-0.127 \\
(0.264)\end{array}$ & $\begin{array}{l}-0.376^{* *} \\
(0.040)\end{array}$ & $\begin{array}{l}-0.403 * * \\
(0.026)\end{array}$ & $\begin{array}{l}-0.692^{*} \\
(0.086)\end{array}$ & $\begin{array}{l}-0.848 \\
(0.217)\end{array}$ \\
\hline & $\begin{array}{l}\text { Training and } \\
\text { grant }\end{array}$ & $\begin{array}{l}0.051 \\
(0.653) \\
\end{array}$ & $\begin{array}{l}0.047 \\
(0.687) \\
\end{array}$ & $\begin{array}{l}-0.070 \\
(0.654) \\
\end{array}$ & $\begin{array}{l}-0.181 \\
(0.693) \\
\end{array}$ & $\begin{array}{l}-0.008 \\
(0.986) \\
\end{array}$ & $\begin{array}{l}-0.038 \\
(0.930) \\
\end{array}$ & $\begin{array}{l}0.009 \\
(0.937) \\
\end{array}$ & $\begin{array}{l}-0.003 \\
(0.973) \\
\end{array}$ & $\begin{array}{l}-0.044 \\
(0.716) \\
\end{array}$ & $\begin{array}{l}0.835 \\
(0.126) \\
\end{array}$ & $\begin{array}{l}0.846 \\
(0.106) \\
\end{array}$ & $\begin{array}{l}-0.002 \\
(0.997) \\
\end{array}$ & $\begin{array}{l}0.036 \\
(0.958) \\
\end{array}$ \\
\hline \multicolumn{15}{|c|}{ Main psychological and behavioral outcomes (experimental measures) } \\
\hline \multirow{2}{*}{$\begin{array}{l}\text { List } \\
\text { experiment } \\
\text { cattle index }\end{array}$} & $\begin{array}{l}\text { Training, no } \\
\text { grant }\end{array}$ & $\begin{array}{l}0.371 * * \\
(0.020)\end{array}$ & $\begin{array}{l}0.376 \\
(0.147)\end{array}$ & $\begin{array}{l}0.435 \\
(0.124)\end{array}$ & $\begin{array}{l}-0.577 \\
(0.325)\end{array}$ & $\begin{array}{l}-0.611 \\
(0.336)\end{array}$ & $\begin{array}{l}-0.614 \\
(0.419)\end{array}$ & $\begin{array}{l}0.117 \\
(0.380)\end{array}$ & $\begin{array}{l}0.152 \\
(0.212)\end{array}$ & $\begin{array}{l}0.181 \\
(0.129)\end{array}$ & $\begin{array}{l}-0.577 \\
(0.325)\end{array}$ & $\begin{array}{l}-0.611 \\
(0.336)\end{array}$ & $\begin{array}{l}-0.614 \\
(0.419)\end{array}$ & $\begin{array}{l}1.112 \\
(0.207)\end{array}$ \\
\hline & $\begin{array}{l}\text { Training and } \\
\text { grant }\end{array}$ & $\begin{array}{l}0.015 \\
(0.946)\end{array}$ & $\begin{array}{l}0.059 \\
(0.643)\end{array}$ & $\begin{array}{l}0.114 \\
(0.474)\end{array}$ & $\begin{array}{l}1.745^{*} \\
(0.078)\end{array}$ & $\begin{array}{l}1.739 \\
(0.104)\end{array}$ & $\begin{array}{l}2.088^{*} \\
(0.097)\end{array}$ & $\begin{array}{l}-0.128 \\
(0.554)\end{array}$ & $\begin{array}{l}-0.146 \\
(0.202)\end{array}$ & $\begin{array}{l}-0.096 \\
(0.462)\end{array}$ & $\begin{array}{l}1.745^{*} \\
(0.078)\end{array}$ & $\begin{array}{l}1.739 \\
(0.104)\end{array}$ & $\begin{array}{l}2.088^{*} \\
(0.097)\end{array}$ & $\begin{array}{l}-2.650^{*} \\
(0.093)\end{array}$ \\
\hline \multirow{2}{*}{$\begin{array}{l}\text { List } \\
\text { experiment } \\
\text { argument } \\
\text { index }\end{array}$} & $\begin{array}{l}\text { Training, no } \\
\text { grant }\end{array}$ & $\begin{array}{l}0.024 \\
(0.900)\end{array}$ & $\begin{array}{l}0.025 \\
(0.899)\end{array}$ & $\begin{array}{l}0.031 \\
(0.874)\end{array}$ & $\begin{array}{l}-1.133 \\
(0.139)\end{array}$ & $\begin{array}{l}-0.787 \\
(0.292)\end{array}$ & $\begin{array}{l}-0.473 \\
(0.399)\end{array}$ & $\begin{array}{l}-0.265^{* *} \\
(0.016)\end{array}$ & $\begin{array}{l}-0.245^{* *} \\
(0.032)\end{array}$ & $\begin{array}{l}-0.291 * * \\
(0.011)\end{array}$ & $\begin{array}{l}-1.133 \\
(0.139)\end{array}$ & $\begin{array}{l}-0.787 \\
(0.292)\end{array}$ & $\begin{array}{l}-0.473 \\
(0.399)\end{array}$ & $\begin{array}{l}0.213 \\
(0.746)\end{array}$ \\
\hline & $\begin{array}{l}\text { Training and } \\
\text { grant }\end{array}$ & $\begin{array}{l}0.191 \\
(0.390)\end{array}$ & $\begin{array}{l}0.131 \\
(0.573)\end{array}$ & $\begin{array}{l}0.192 \\
(0.411)\end{array}$ & $\begin{array}{l}2.195^{* *} \\
(0.044)\end{array}$ & $\begin{array}{l}1.662 \\
(0.108)\end{array}$ & $\begin{array}{l}1.306 \\
(0.134)\end{array}$ & $\begin{array}{l}-0.488^{* *} \\
(0.029)\end{array}$ & $\begin{array}{l}-0.501^{* *} \\
(0.036)\end{array}$ & $\begin{array}{l}-0.451^{*} \\
(0.052)\end{array}$ & $\begin{array}{l}2.195 * * \\
(0.044)\end{array}$ & $\begin{array}{l}1.662 \\
(0.108)\end{array}$ & $\begin{array}{l}1.306 \\
(0.134)\end{array}$ & $\begin{array}{l}-2.011^{*} \\
(0.085)\end{array}$ \\
\hline
\end{tabular}




\begin{tabular}{|c|c|c|c|c|c|c|c|c|c|c|c|c|}
\hline \multirow{2}{*}{$\begin{array}{l}\text { Observatio } \\
\text { ns } \\
\text { F-stat }\end{array}$} & 555 & 547 & 541 & 547 & 541 & 541 & 968 & 948 & 933 & 953 & 933 & 933 \\
\hline & & & & 4.510 & 4.568 & 19.85 & & & & 5.330 & 5.268 & 15.76 \\
\hline
\end{tabular}

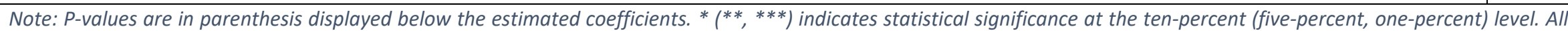

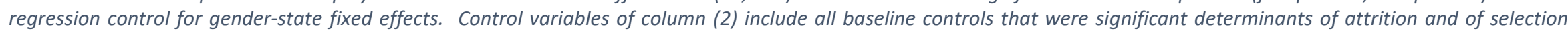
between receiving "training and grant" vs "training, but no grant". In particular, these are age, marital status, employment status, business ownership, food consumption, non-

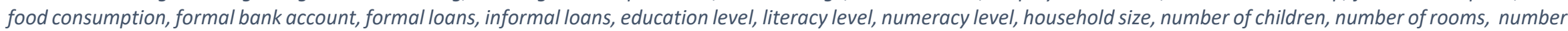
of buildings at baseline, and conflict exposure between baseline and endline. Column (3) also controls for geographic features since the estimation strategy relies on the distance to the closest KCB bank branch that might correlate with other geographic characteristics. . Geography controls include distance to the closest city, distance to the closest road, average land gradient and their respective interactions with selection to the original treatment group and the interaction between conflict exposure and original treatment group. Column (13) reports tests for coefficient equality between estimates from males and females in column (6) and (12). Displayed are differences of coefficient p-values of the test in parenthesis. 


\section{Appendix 4 - Methodological details on experimental games}

\section{Lotteries}

This study uses choices over lotteries that vary in expected return and variance to extract risk preferences. In the endline, data collection respondents were asked to choose between two or three alternative lotteries. The design of this experiment involved eight rounds, building on research design by (Jakiela and Ozier 2015). After choosing one option, the chosen lottery was played as a flip of a fair coin (50 percent chance of each outcome). The game started with two practice rounds to make participants familiar with the rules. After that, the participants had to play six additional rounds. At the end of the game, one round was selected at random and the lottery chosen by the participants was played and paid out. Participants were informed about these rules at the beginning of the game. The lotteries are set up as described below in table A4.1.

The number of times respondents chose the riskiest lottery can be used as a proxy for their risk preferences. Given that respondents in these types of experiments often display choices that are inconsistent with CRRA utility a non-parametric approach to measure risk aversion is more appropriate. Thus, following the approach put forward by Jakiela and Ozier (2015) the set of lottery choices can also be used to infer risk preferences in a less stringent and non-theoretic manner. One measure is created by counting how many times respondents choose the riskiest lotteries, i.e. lotteries with the largest spread, or the safest lotteries. In addition, the likelihood to choose the riskier lottery during each decision round was evaluated individually. The results are then compared to survey answers on risk preferences.

Test questions were included to detect biased answers that resulted from a lack of understanding. Due to the relatively low numeracy skills and the complexity of the lotteries, the study included 3 questions to test for monotonicity, i.e. if participants behaved like utility-maximizers (Andreoni and Sprenger 2010). If participants answered more than 1 of these test questions in a way inconsistent with utility maximization, it is likely that they simply did not understand the nature of the decision problem.

\begin{tabular}{|} 
Table A4.1 Pay-outs of lotteries, expected utility \\
\begin{tabular}{|c|c|c|c|c|c|c|}
\hline & Lottery A & \multicolumn{2}{c|}{ Lottery B } & \multicolumn{2}{c|}{ Lottery C } \\
\hline & Heads & Tails & Heads & Tails & Heads & Tails \\
\hline \multicolumn{7}{|c|}{ Practice } \\
\hline Decision 1 & 100 & 100 & 150 & 150 & & \\
\hline Decision 2 & 100 & 150 & 200 & 250 & & \\
\hline \multicolumn{7}{|c|}{ Game } \\
\hline Decision 3 & 100 & 100 & 100 & 120 & & \\
\hline Decision 4 & 100 & 100 & 0 & 400 & & \\
\hline Decision 5 & 30 & 340 & 100 & 100 & 0 & 400 \\
\hline Decision 6 & 100 & 100 & 55 & 240 & 30 & 340 \\
\hline
\end{tabular}
\end{tabular}




\begin{tabular}{|l|l|l|l|l|l|l|}
\hline Decision 7 & 30 & 230 & 60 & 170 & 90 & 110 \\
\hline Decision 8 & 10 & 200 & 70 & 160 & 90 & 110 \\
\hline
\end{tabular}

\section{Trust game}

Trust attitudes towards the World Bank were assessed using a trust game. The basic structure of a trust game developed by Berg, Dickhaut, and McCabe (1995) involves Player A receiving an endowment of $X$ and choosing how much of this endowment to send to Player $B, Y \in[0, X]$. Player $B$ receives $3 Y-$ i.e., three times whatever $A$ send him - and must decide how much of this endowment to send back to $A, Z \in[0,3 Y]$. A receives a payout of $X-Y+Z$ and $B$ receives a payout of $3 Y-Z$. $Y / X$ is used as a measure of trust. $\mathrm{Z} / 3 \mathrm{Y}$ is used as a measure of trustworthiness. The table below summarizes payouts for the two players:

Table A4.2 Trust game payouts

\begin{tabular}{|c|c|l|l|l|l|}
\hline \multicolumn{2}{|l|}{ Player 1 } & Player 2 \\
\hline Endowment & Sends & Payout & Endowment & Sends & Payout \\
\hline$X$ & $Y$ & $X-Y+Z$ & $3 Y$ & $Z$ & $3 Y-Z$ \\
\hline
\end{tabular}

In our study, participants were asked to play several rounds of a trust game. In the first game, Player B was framed as the World Bank to extract a measure of trust toward the World Bank or official institutions in general. Participants may hold the World Bank responsible for the (non-) payment of the business start-up grants. This framing of Player B as the World Bank allows for a direct measure of how willing participants are to partake in an interaction with the World Bank that could have financial consequences. Hence, it can act as a measure of how not receiving the promised grant had influenced their level of trust and their willingness to interact with the World Bank. The reciprocal behavior of Player B was modeled to mirror the probability of non-disbursement of the cash grant. In 34 percent of the cases documented by the phone survey, participants received the grant. This information was used to define the reciprocal behavior of Player B. Player B played fairly 34 percent of the time - that is, returns back exactly half of what they obtain from the study participant. Player B 66 percent of the time acted unfairly and kept all that is sent to them, regardless of what the respondent sent. In the end, the participant was paid out the budget of Player A.

To obtain a more general measure of the respondents' trust levels, and to accompany the first measure, a second game was played which pit the participants against each other. The survey respondents were equally and randomly selected as players $A$ and $B$, stratified by treatment groups and treatment strands. Regarding the implementation of the games and pairing of the players, a labin-the-field experimental setup was impossible to organize because respondents had to be interviewed 
individually. This was primarily due to the complicated logistical circumstances surrounding fieldwork in South Sudan, in no small part due to rapidly deteriorating security conditions, but also due to constraints on the respondents' time. Respondents were, therefore, playing the games against a preloaded hypothetical distribution of responses. Enumerators explained to the respondents that the other player would be another survey respondent elsewhere in South Sudan. The set of possible responses, in terms of the fraction of the endowment sent or returned, was equally distributed between $[0.1,1]$ in increments of 0.1 . In no cases was the fraction of endowment sent or returned equal to zero.

\section{List-experiment}

Based on the results from the baseline survey, it was determined that the reporting of sensitive behaviors might have been untruthful. Methods to elicit more truthful responses were therefore employed in the endline questionnaire. For example, the rates at which respondents reported even simply knowing someone who may have participated in cattle raiding were close to zero, despite 63 percent of respondents reporting cattle raiding in their area in the baseline. Rates of reporting respondents' own sensitive behaviors were even lower. Therefore, a set of list questions - also commonly known as the "item count technique" introduced by Miller (1984) - were added to the endline questionnaire. In these questions, the sample is split into a treatment and control group, and respondents in the control group are given a set of $\mathrm{N}$ statements and asked to answer with how many of these statements do they agree with/or would say yes to, without explicitly stating which ones. Respondents in the treatment group are given the same $\mathrm{N}$ statements + a sensitive item. The estimate of the true rate at which respondents agree with the sensitive statements is simply the difference in means, in terms of the number of statements, between the treatment and control groups. In the context of the endline survey, the sensitive behaviors pertained to violent behavior, including domestic violence, as well as cattle raiding. Direct questions were asked to the control group alongside the list question without the sensitive item, so as to compare results obtained through the list-method. Below we report the list of sensitive items included in the experiment.

Figure A4.1 List of sensitive statements included in the list experiment

\section{Cattle raiding:}

1. I know someone who has participated in cattle raiding, including myself.

2. I have participated in cattle raiding.

Violent behavior:

1. I have had a verbal disagreement in the last month where the other person threatened me with violence.

2. I have had a verbal disagreement in the last month where I threatened the other person with violence. 
3. I have had a verbal disagreement with someone in the last month which ended with violence. 
Appendix 5 - Index creation

Following Anderson (2008) Indexes $s_{j i}$ is defined as a weighted average of all standardized outcomes $k$ within outcome group $j$.

$$
s_{i j}=\frac{1}{W_{i j}} \sum_{k} w_{i k} \frac{y_{i j k}-\bar{y}_{j k}}{\sigma_{j k}^{y}}
$$

Weight $w_{j k}$ of each outcome $k$ is derived from the inverted covariance matrix of all standardized outcomes $k$.

$$
\sum_{j}^{-1}=\left[\begin{array}{ccc}
c_{j 11} & \cdots & c_{j 1 K} \\
\vdots & \ddots & \vdots \\
c_{j K 1} & \cdots & c_{j K K}
\end{array}\right]
$$

Weight $\mathrm{w}_{\mathrm{jk}}$ then consists of the row sum of the inverted covariance matrix.

$$
w_{j k}=\sum_{l=1}^{K_{j}} c_{j k l}
$$


Appendix 6 - Additional figures

Figure A6.1 Map of participants' baseline locations, major cities of project states and KCB bank branches

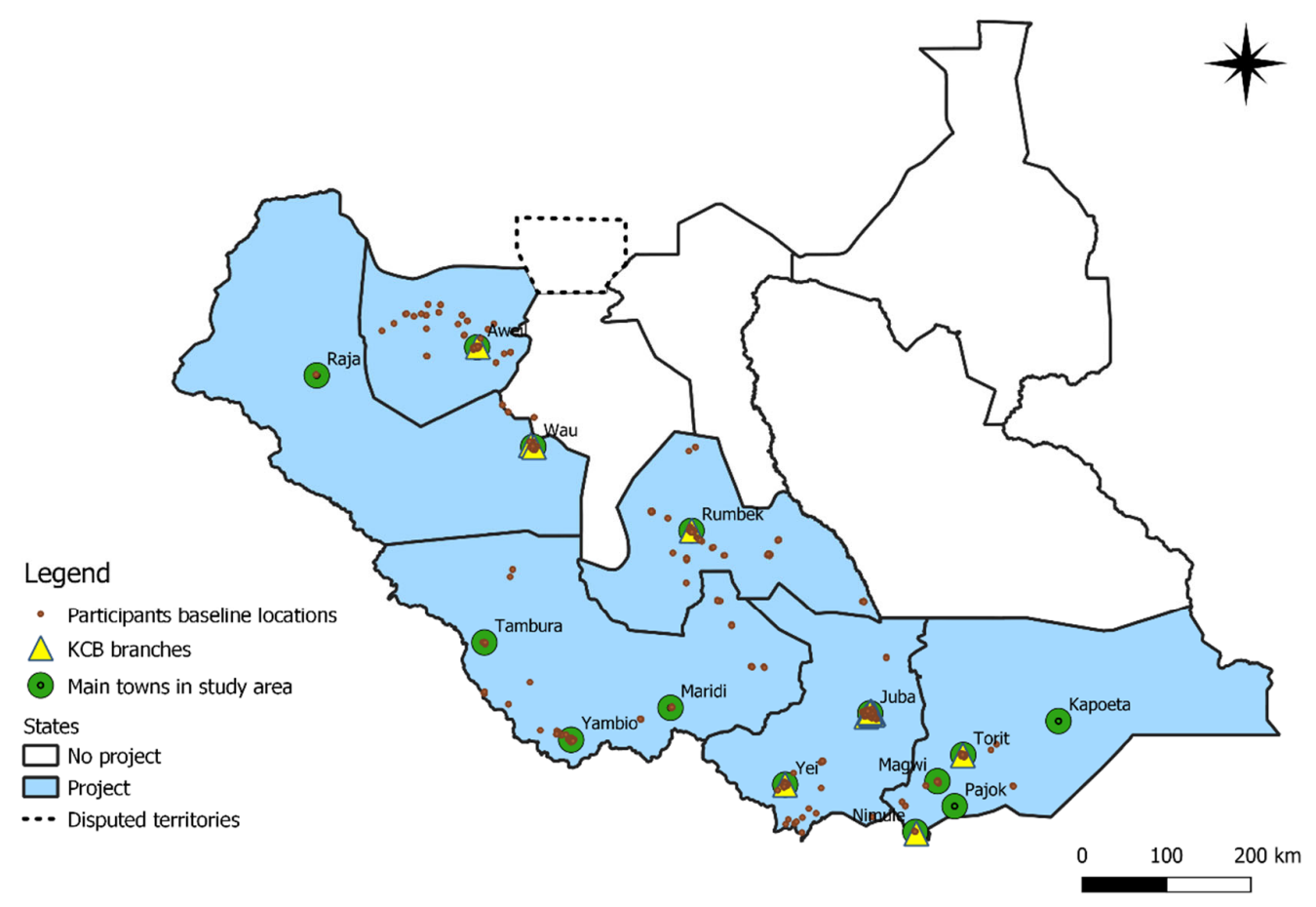



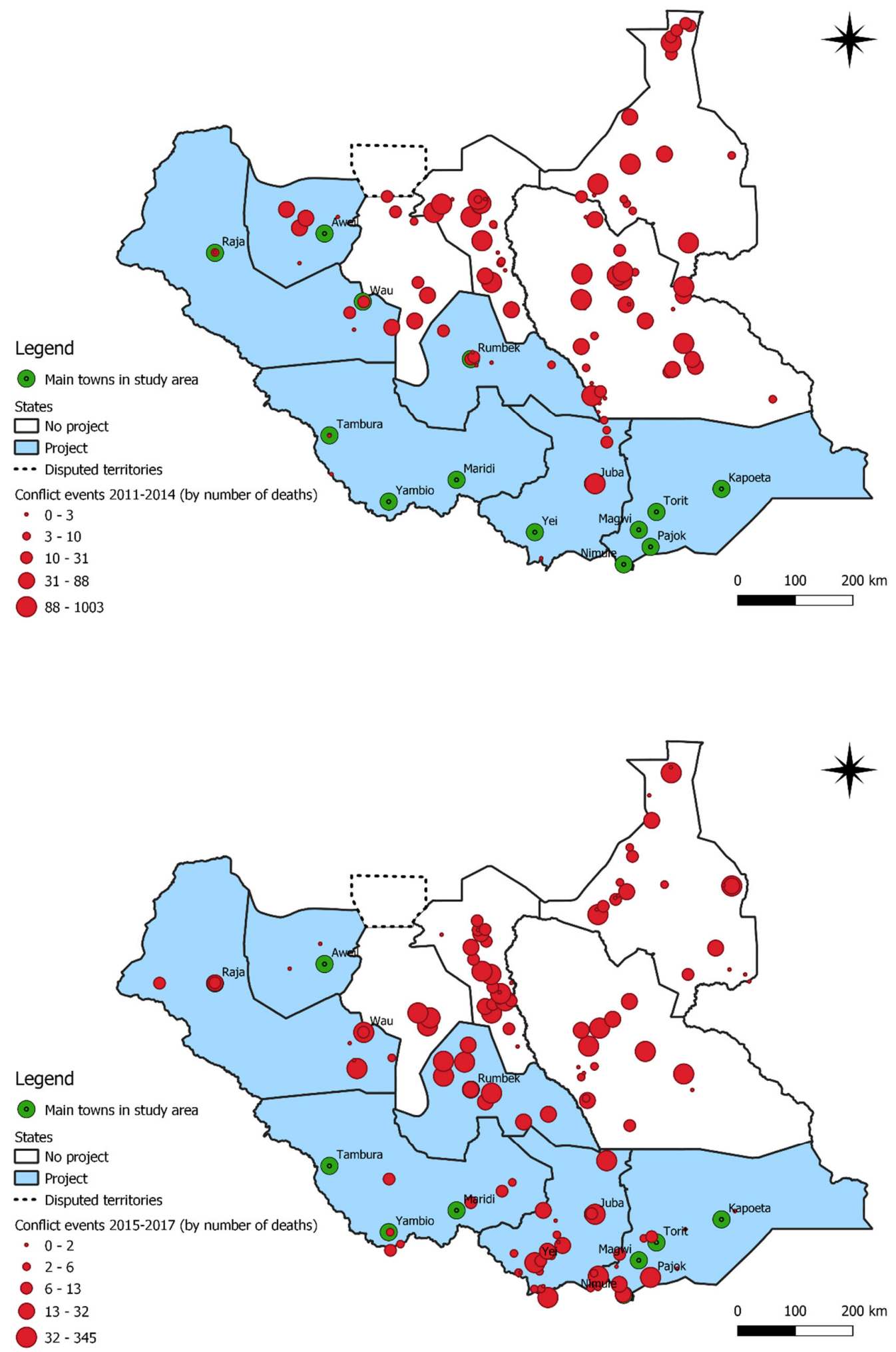